\title{
GOOD AND BAD PRAYERS, BEFORE ALBERTUS PICTOR: PROLEGOMENA TO THE HISTORY OF A LATE MEDIEVAL IMAGE
}

"Lay not up to yourselves treasures on earth: where the rust, and moth consume, and where thieves break through and steal. But lay up to yourselves treasures in heaven: where neither the rust nor moth doth consume, and where thieves do not break through, nor steal. For where thy treasure is, there is thy heart also... No man can serve two masters. For either he will hate the one, and love the other: or he will sustain the one, and despise the other. You cannot serve God and mammon." Matthew 6:19-21, 24

The visual allegory of the Good and the Bad Prayer is one of the rarest - and one of the most intriguing - pictorial creations of the later Middle Ages. In most of the forty or so known examples, a pious, poor man and a distracted, rich man, both in attitudes of prayer, face one another on either side of the suffering Christ, shown either crucified or as the Man of Sorrows. A key feature of the image are the bundles of thought- or prayer-lines that indicate and link both men to the respective objects of their innermost ruminations - the wounds of Christ in the case of the pious individual, and an inventory of worldly possessions, often displayed

DOI: http://dx.doi.org/10.12697/BJAH.2013.5.07

1 Douay-Rheims translation of the Vulgate passage: Nolite thesaurizare vobis thesauros in terra: ubi aerugo, et tinea demolitur: et ubi fures effodiunt, et furantur. Thesaurizate autem vobis thesauros in caelo, ubi neque aerugo, neque tinea demolitur, et ubi fures non effodiunt, nec furantur. Ubi enim est thesaurus tuus, ibi est cor tuum... Nemo potest duobus dominis servire: aut enim unum odio habebit, et alterum diliget: aut unum sustinebit, et alterum contemnet. Non potestis Deo servire et mammonae. 
within a tall, multi-storied building, in the case of his wealthy counterpart. The Good and the Bad Prayer imaginatively translates into visual language a prominent passage from the Sermon of the Mount (Matthew 6:19-24), in which Christ admonishes his audience to collect heavenly over worldly treasures - or face the consequences. The image provides a veritable object lesson in the making of pictorial allegory on the eve of the Protestant Reformation, and takes us straight to the heart of the Church Reform of the later fourteenth and fifteenth centuries, with its agenda of pastoral instruction, promotion of various techniques of lay prayer, and the concomitant condemnation of the ethics and practices of materialism and conspicuous consumption. Yet, despite its rich cultural and iconographical resonances, the representation of the Good and Bad Prayer has never been the subject of a more focused and sustained investigation. Apart from a series of brief articles (often mere notices) on individual images published since the $1930 \mathrm{~s}^{2}$ the only comprehensive study of the allegory remains an essay by the Swiss folklorist Robert Wildhaber, published in 1967 and later condensed into an entry for the second volume of the Lexikon der christlichen Ikonographie (1970). ${ }^{3}$ More recently, the image has also come to the attention of historians of material

2 See, for instance, Andor Pigler, "Evagationes spiritus: Egy képmagyarázet és adatok az eszergomi Keresztény Múzeum festményeinek történetéhez”, Archaeologiai értesitö, 46 (1932-1933), 121-136; Guy De Tervarent, "En marge du catalogue du Prado", Gazette des Beaux-Arts, 78 (1936), 59-60; Hans Haug, "La Prière du riche et du pauvre", Gazette des Beaux-Arts, 79 (1937), 190-192; Jacob Por, "Een merkwaardige schildering in de Groote Kerk te Breda," Oud-Holland, 60 (1943), 37-44; Karen Wisselaar, "Evagationes spiritus: Het geode en slechte gebet in de Onze-Lieve-Vrouwekerk te Breda", Madoc: tijdschrift over de middeleeuwen, 13 (1997), 164-172.

3 Robert Wildhaber, "Das gute und das schlechte Gebet: Ein Beitrag zum Thema der Mahnbilder", Europäische Kulturverflechtungen im Bereich der volkstümlichen Überlieferung: Festschrift zum 65. Geburtstag Bruno Schiers, ed. by Gerhard Heilfurth, Heinrich Siuts, Veröffentlichungen des Instituts für mitteleuropäische Volksforschung an der Philipps-Universität Lahn, 5 (Göttingen: Schwartz, 1967), 63-72; idem, "Gebet, gutes und schlechtes", Lexikon der christlichen Ikonographie, 2, ed. by Engelbert Kirschbaum et al., (Rome, Freiburg, Basel \& Vienna: Herder, 1970), 82-84. 
culture,${ }^{4}$ ethnographers, ${ }^{5}$ theologians, ${ }^{6}$ historians of medieval German literature, ${ }^{7}$ and a select group of art and visual historians based around the Baltic Sea. It is indeed here, along the shores and in the hinterland of the former spheres of influence of the Hanseatic League and the Teutonic Knights that most of the surviving examples of the Good and Bad Prayer are to be found, almost exclusively in the medium of wall painting and often in tandem with other didactic types of images. In so far as this peculiar geographical distribution has elicited a scholarly response at all, it has done so mainly in the context of research conducted on a series of teams of itinerant muralists active in both eastern Denmark and southeastern Sweden during the half-century before the Protestant Reformation (c. 1470 - c. 1520). While the so-called Elmelunde Master seems to have introduced the Good and Bad Prayer to the Danish islands of Møn and Falster, ${ }^{8}$ a second workshop, headed by the equally now anonymous Everlöv Master (a possible pupil of the Elmelunde Master), brought the iconography to Skåne in southern Sweden (then politically a part of Denmark). ${ }^{9}$ The imagery is perhaps most famously associated with the

4 See in particular Gerhard Jaritz, "Ira Dei, Material Culture, and Behavior in the Late Middle Ages: Evidence from German-Speaking Regions", Essays in Medieval Studies, 18 (2001), 53-66; idem, "Das schlechte Gebet zu den Schätzen der Welt", Vom Umgang mit Schätzen: Internationaler Kongress, Krems an der Donau, 28. bis 30. Oktober 2004. Österreichische Akademie der Wissenschaften, philosophisch-historische Klasse, Sitzungsberichte, 771 (Vienna: Verlag der Österreichischen Akademie der Wissenschaften, 2007), 81-97.

5 See most notably the contributions by Leopold Kretzenbacher, "Ein Innviertler Mahnbild-Fresko zu Polling", Österreichische Zeitschrift für Volkskunde, 30 (1976), 118-125; idem, "Drei altösterreichische Mahnbild-Zeugnisse pastoral gelenkter Volksfrömmigkeit", Zeitschrift des historischen Vereins für Steiermark, 8 (1993), 127-139.

6 Some examples of the image are briefly considered in Thomas Lentes, "Inneres Auge, äußerer Blick und heilige Schau: Ein Diskussionsbeitrag zur visuellen Praxis und Moraldidaxe des späten Mittelalters", Frömmigkeit im Mittelalter: Politisch-soziale Kontexte, visuelle Praxis, körperliche Ausdrucksformen, ed. by Klaus Schreiner (Munich: Fink, 2002), 179-219, 185-186; and Viktor Aldrin, The Prayer Life of Peasant Communities in Late Medieval Sweden: A Contrast of Ideals and Practices (Lewiston, NY: The Mellen Press, 2011), 83.

7 See, for instance, the relevant passages in Eckart Conrad Lutz, "Spiritualis fornicatio: Heinrich Wittenwiler, siener Welt und sein 'Ring'", Konstanzer Geschichts- und Rechtsquellen, 32 (Sigmaringen: Thorbecke, 1990), 274, 331, 389-390; and Stefan Abel, “Johannes Nider 'Die vierundzwanzig goldenen Harfen“, Spätmittelalter, Humanismus, Reformation, 60 (Tübingen: Mohr Siebeck, 2011), 405-406.

8 On the Elmelunde Master, to whom at least fourteen extensive mural programmes are attributed, see esp. Karen Elisabeth Hammer, Sakrale Wandmalerei in Dänemark und Norddeutschland im ausgehenden Mittelalter: Eine Studie zu den Malereien der Elmelundegruppe in Sakralräumen Süddänemarks unter besonderer Berücksichtigung der Kirche zu Fanefjord sowie der norddeutschen Wandmalerei (Ammersbek: Verlag an der Lottbek, 1990).

9 For the Everlöv workshop, which is credited with the decoration of over a dozen churches in Skåne and the Danish islands of Lolland and Falster, see Knud Banning (ed.), A Catalogue of Wall-Paintings in the Churches of Medieval Denmark, 1100-1600: Scania, Halland, Blekinge, 4 vols (Copenhagen: Akademisk Førlag, 1976-1982), passim. 
name of Albertus Pictor (Albert målare), who may have received his initial training in northern Germany during the 1450s before decorating a whole series of parish churches in western Uppland, Vätmanland and Södermanland between 1465 and his death sometime around $1509 .{ }^{10}$ The precise extent of his œuvre is still subject

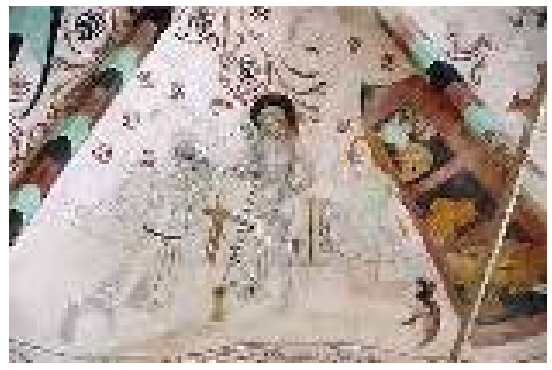

Fig. 1a. Härnevi (Uppland), parish church, Good and Bad Prayer, c. $1470-1480$ by Albertus Pictor to an ongoing debate, though at least nine of the churches attributed to him or members of his shop feature a representation of the Good and Bad Prayer, often in the porch or vapenhus, where in conjunction with a whole range of other moralizing, eschatological or exorcistic images the allegory served to frame and structure the experience of entering the sacred building (fig. 1). ${ }^{11}$ Pia Melin's examination of these highly didactic image cycles, published in 2006, also contains a brief chapter on the Good and Bad Prayer, as imagined and depicted by Albertus and his troupe of artists, which to date represents the single most extensive treatment of this iconography. ${ }^{12}$

There is, then, a growing, if still modest, awareness of, and interest in, the allegory of the Good and Bad Prayer across a variety of academic disciplines. With this contribution, which both builds on and expands from previous scholarship, I hope to stimulate further research into both the origins of this fascinating image and its eventual application

10 For Albertus Pictor and his artistic trajectory, see esp. Jan Öberg, Erika Kihlman, Pia Melin (eds.), Den mångsidige målaren: Vidgade perspektiv på Albertus Pictors bild-och textvärld: Föredrag från ett symposium vid Stockholms universitet oktober 2005 (Stockholm: Sällskapet Runica et mediævalia, 2007); Pia Melin, Fåfängans förgänglighet: Allegorin som livs- och lärospegel hos Albertus Pictor (Stockholm: Stockholmia, 2006); Margareta Kempff, “Albertus Pictor”, Allgemeines Künstlerlexikon: Die Bildenden Künstler aller Zeiten und Völker, 2 (Leipzig: Saur, 1992), 117-118; Henrik Cornell, Albertus Pictor: Sten Stures und Jacob Ulvssons Maler: Seine Stellung innerhalb der europäischen Kunst; seine Bedeutung in Schwedens künstlerischem und religiösem Leben (Stockholm: Kungl. Vitterhets historie och antikvitets akademien, 1981); but see also Anna Nilsén, Program och funktion i senmedeltida kalkmåleri: Kyrkmålningar i Mälarlandskapen och Finland, 1400-1534 (Stockholm: Kungl. Vitterhets historie och antikvitets akademien, 1986).

11 On these spaces and their pictorial decoration, see Ingalill Pegelow, "Från Helga Lekamen - till Blåkulla: Vapenhusmålninger i uppländska kyrkor," Bild och betydelse: Föredrag vid det 4. nordiska symposiet för ikonografiska studier, Kvarnträsk, 19.-22. augusti 1974, ed. by Louise Mille, Mogens Thøgersen (Åbo: Åbo Akademi, 1976), 215-227.

12 Melin, Fåfängans förgänglighet, 122-133. 


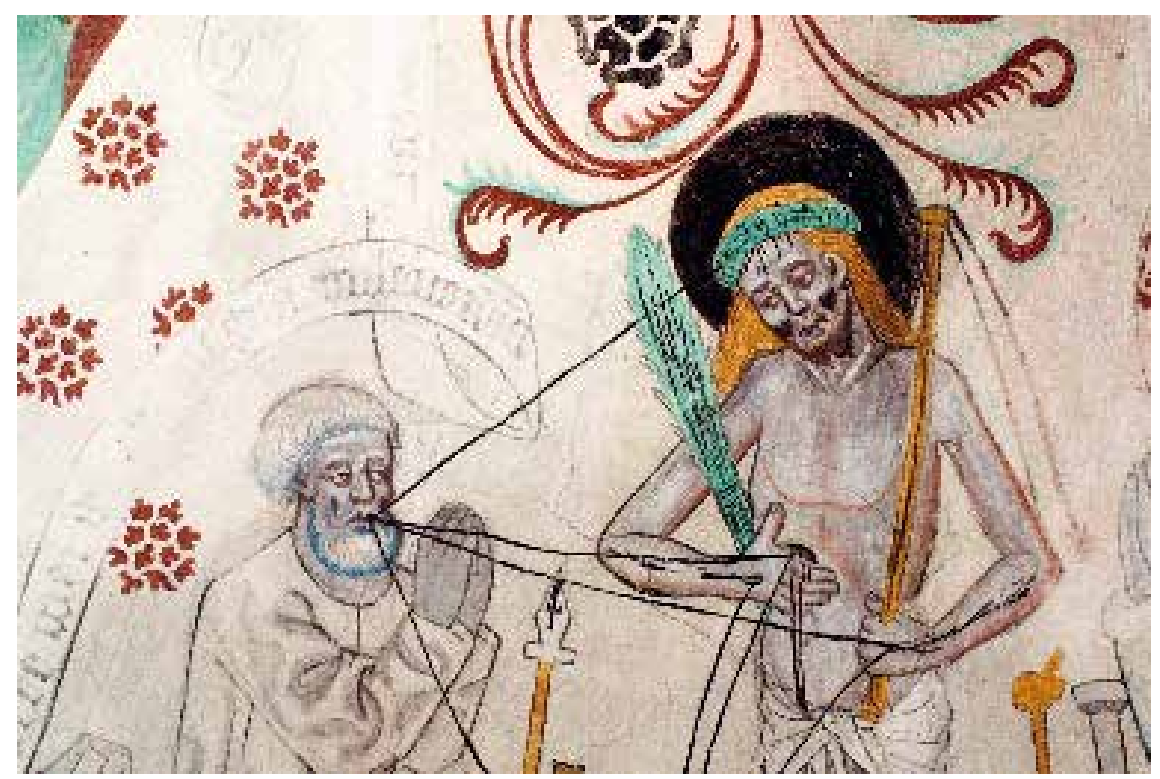

Fig. 1b. Härnevi (Uppland), parish church, Good and Bad Prayer, c. 1470-1480 by Albertus Pictor; detail

to various physical, semantic and experiential frameworks. My aim in this article is threefold: First, I will attempt an outline of what may be called a diachronic history of the Good and Bad Prayer before its introduction to southeastern Sweden by Albertus Pictor in the 1470s. Needless to say, because of the very low survival rate this story comes, at least for the time being, with its fair share of missing links, raising at this point perhaps more questions than providing answers. Second, I wish to tease out some of the broader iconographical and cultural implications of the image, proposing various (partially overlapping) rings of enquiry within which it can be effectively examined. And third, to facilitate subsequent research on the Good and Bad Prayer and to provide easier access to depictions that have so far eluded scholarship, my investigation concludes with a preliminary catalogue of those examples known to me at the time of writing (June 2013), forty-one in all. ${ }^{13}$ It is hoped that in time many more representations of this important image will come to light and be added to this steadily growing corpus.

13 Wildhaber, "Das gute und das schlechte Gebet: Ein Beitrag" and his subsequent entry for the Lexikon der christlichen Ikonographie, lists twelve examples. No other attempt to catalogue the extant images has been made. 
Judging by what has survived it appears that almost from its very inception in the fourteenth century, the Good and Bad Prayer would have been most frequently encountered in the context of mural cycles designed for parish churches or hospital chapels, and largely directed at lay audiences. It may therefore come as a bit of a surprise to find the earliest known instance of this iconography (fig. 2) in a manuscript intended for the theological instruction and moral edification of nuns and

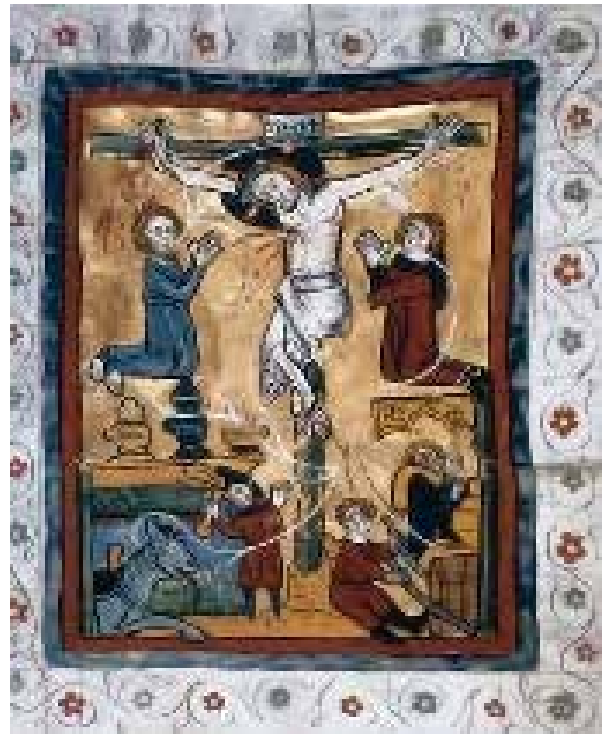

Fig. 2. Engelberg, Cod. 62, fol. 17r, Good and Bad Prayer, c. 1330 novices - a richly illuminated Latin Psalter produced in c. 1330 for the Benedictine double (male and female) convent of Engelberg in central Switzerland (Engelberg Cod. 62; cat. no. 7)..$^{14}$ The allegory (fol. 17r) figures as part of a sequence of twenty-four prefatory, full-page miniatures and is paired with the representation of the Throne of Solomon on the opposite page (fol. 16v). Despite its early date, the image already appears fully-formed, its principal components and disposition differing little from those versions produced during the fifteenth and even sixteenth centuries. A very bloodied Christ is flanked here by two praying men, the dexter one bearded, with unkempt hair, a simple, long robe and bare feet (nudis pedibus), the other, on His sinister side, clean-shaven and wearing a fashionable long-sleeved mantle and buckled shoes. Thin, white lines or cords as delicate as spider's silk issue from the mouths of the two men and attach themselves to the true sites of their most ardent imaginings, which Matthew 6:19 respectively identifies as the thesaurus in caelo and the thesaurus in terra. While the cords of the poor and pious man form umbilicals that link him to the Saviour's spraying stigmata, the rich man's thoughts dwell, despite his exterior attitude of genuflect

14 I thank Orsolya Mednyánszky for helping me locate this example. 
prayer, in an altogether different place, as he longingly revisits in his mind an inventory of his riches. Whereas one strand leads to a kind of cellar, into or from which a servant carries a sack of grain (or gold?) and in which another busies himself with a large wine barrel, a different bundle of lines has affixed itself to a caparisoned horse with its groom. Finally, a third string of cords reveals to the viewer a table on which various banqueting vessels are ostentatiously displayed. ${ }^{15}$

Just what prompted the nuns of Engelberg to incorporate this unusual image into the prefatory cycle of their Psalter is as difficult to determine as the question whether this representation was copied or adapted from an even older (and now lost) source or whether indeed it was here, in this very manuscript, that the allegory of the Good and Bad Prayer had its iconographical premiere. On the one hand, given the intended audience, the choice of a pair of laymen as the image's principal pictorial protagonists may strike one as rather peculiar (a second Crucifixion allegory in this manuscript, on fol. $12 \mathrm{v}$, shows Christ being nailed to the cross by female personifications of virtues). On the other hand the double community of Engelberg was well-connected and intellectually vibrant, and would have provided an ideal environment for the level of sophisticated pictorial reasoning expressed in the allegory. ${ }^{16}$ Precedents for this kind of monastic image making certainly abound; it may suffice here to draw attention to the contributions made to the development of visual allegory by compendia such as the Benedictine Hortus deliciarum (1167- 1185) $)^{17}$ or to the galvanizing influence which the Dominican

15 Rather incongruously, perhaps, one has its lid removed, catching precious droplets from Christ's dulce vulnus laterale.

16 During the thirteenth century Engelberg enjoyed the protection of both the Habsburgs and Holy See; in the central decades of the fourteenth century the abbey came under the spell of the charismatic Engelberg Preacher, who introduced the double convent to the basic tenets of Dominican mysticism; see Elsanne Gilomen-Schenkel, "Engelberg”, and Kurt Ruh, "Engelberger Prediger”, both in Lexikon des Mittelalters, III (Munich \& Zürich: Artemis, 1986), 1914-1916. For other types of image programmes commissioned from Engelberg's scriptorium during the fourteenth century, see Susan Marti, "Malen, Schreiben und Beten: Die spätmittelalterliche Handschriftenproduktion im Doppelkloster Engelberg“, Züricher Schriften zur Kunst-, Architektur- und Kulturgeschichte, 3 (Zürich: ZIP, 2002). 17 See Heike Willeke, Ordo und Ethos im Hortus Deliciarum: Das Text-Bild-Programm des Hohenburger Codex zwischen kontemplativ-spekulativer Weltschau und pragmatischer Handlungsorientierung, unpublished PhD dissertation (University of Hamburg: 2004); Rosalie Green (ed.), "Hortus deliciarum", Studies of the Warburg Institute, 36 (London: The Warburg Institute, 1979). 


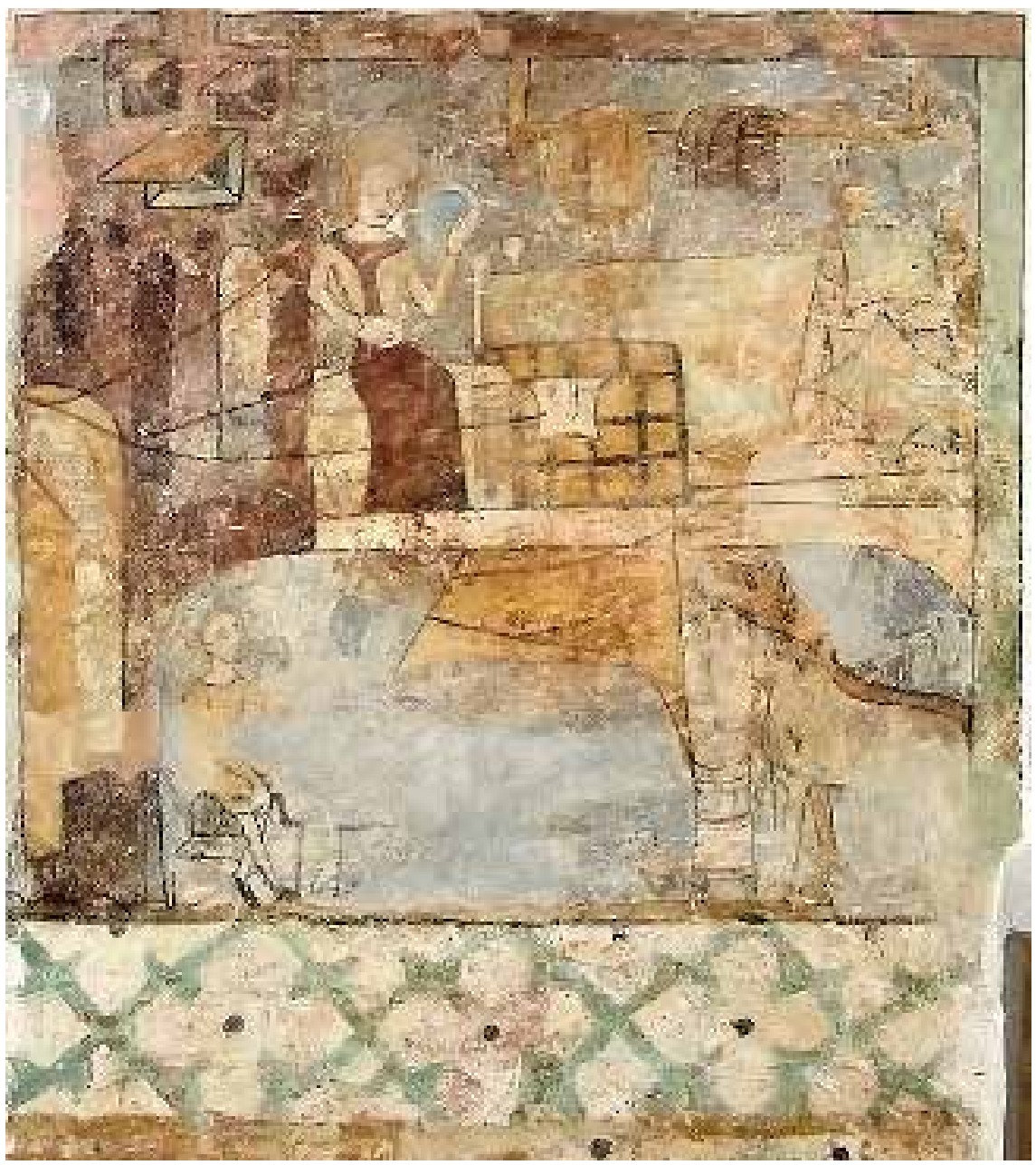

Fig. 3. Wismar, Heiliggeistspital, Good and Bad Prayer (fragment), c. 1380-1400

Speculum humanae salvationis (c. 1310-1320) exerted on the formation of late medieval Marian and Passion iconography. ${ }^{18}$

After its putative debut amidst the folios of the Engelberg manuscript, the image of the Good and Bad Prayer seems to disappear from view for a half-century or so, before resurfacing again in the medium of wall

18 This impact has been studied most recently by Heather M. Flaherty, The Place of the Speculum Humanae Salvationis in the Rise of Affective Piety in the Later Middle Ages, unpublished PhD dissertation (University of Michigan: 2006). 
painting in two disparate localities at once toward the end of the fourteenth century. The story of the allegory now bifurcates, with one strand unraveling in the cities of the Hanse and the Prussian Confederation, the other leading to the valleys and foothills of Styria and the South Tyrol. There is yet a third aspect to this narrative, that of portable media such as drawings and prints, which may explain how the imagery was transmitted from one place to another, often across considerable geographical distances.

Our investigation next takes us to the Hospital Church of the Holy Spirit in the Hanseatic port of Wismar, which preserves on its north nave wall a pair of now-fragmentary murals of the Three Living and the Three Dead and of the Good and Bad Prayer (fig. 3; cat. no. 40). ${ }^{19}$ Dating to c. $1380-1400,{ }^{20}$ these paintings were initially located on either side of a door that gave access to the hospital cemetery inside the adjacent cloister quadrangle. Thus positioned, the two images - one a memento mori, ${ }^{21}$ the other encouraging the renunciation of material objects and concerns - would have invested the act of moving from the world of the living to the world of the dead with a particular and perhaps deliberately unsettling kind of urgency. All that survives today of the Good and Bad Prayer is the rich man's thesaurus, which is represented here not as an assembly of individual scenes, as in the Engelberg Psalter, but as being contained within a two-storied building fronted, like Wismar's great Kontorhäuser, by a narrow brick façade with a stepped gable and shuttered storage attic windows. In this house of unsalutory memories the

19 Both were uncovered in 1968 and restored 1973-1974; see Heinrich Nickel, Mittelalterliche Wandmalerei in der DDR (Leipzig: Seemann, 1979), 295.

20 This date is suggested by the post-Parlerian attire of the one surviving king in the painting of the Three Living and the Three Dead (courtly, forked beard; short, tightly-fitting, slim-waisted tunic with decorated Dupsing belt). The murals were partially destroyed in 1410-1420, when two chapels were added to the north side of the nave; see Hans-Christian Feldmann (ed.), "Mecklenburg-Vorpommern", Dehio Handbuch der deutschen Kunstdenkmäler (Munich \& Berlin: Deutscher Kunstverlag, 2000), 692. 21 For the imagery of the Three Living and the Three Dead, see, most recently, Ashby Kinch, Imago mortis: Mediating Images of Death in Late Medieval Culture (Leiden: Brill, 2013); Marie-Laure de Contenson, "Le Dict de trois morts et des trois vifs d'Ennezat (Puy-de-Dôme): aspects iconographiques et littéraires", L'Iconographie: etudes sur les rapports entre textes et images dans l'Occident medieval, ed. by Gaston Duchet-Suchaux (Paris: Léopard d'Or, 2001), 11-48; Bérénice Terrier, "Le 'Dict des trois morts et des trois vifs' et sa representation murale dans le centre de la France“, Art sacré, 14 (2001), 128 143; Friederike Wille, "Quod sumus hoc eritis: Die Begegnung der Lebenden und Toten im Regnum der Anjou", Medien der Macht: Kunst zur Zeit der Anjous in Italien, ed. by Tanja Michalski (Berlin: Reimer, 2001), 225-239; Vifs nous sommes, morts nous serons: La Rencontre des trois morts et des trois vifs dans la peinture murale en France (Vendôme: Éditions du Cherche-Lune, 2001); still fundamental is Willy Rotzler, Die Begegnung der drei Lebenden und der drei Toten: Ein Beitrag zur Forschung über die mittelalterlichen Vergänglichkeitsdarstellungen (Winterthur: Keller, 1961). 
rich man's thoughts are arranged in all their vainglorious depravity: here a slim-waisted woman, perhaps his wife or mistress, lovingly admires herself in a mirror, while next to her a soft bed with stuffed pillows invites repose or bodily pleasures; there, a locked chest (Kastentruhe) with iron hinge straps and lock plate beckons to be opened while from a rack above hang sumptuous garments; on the floor below, in the servants' sphere, a cook prepares a roast over a spit, whereas in a stable, two horses, a bay and a grey, await their master's command. All of these props embody par excellence the world of things as described in Matthew 6:19 ("where the rust, and moth consume, and where thieves break through and steal"), while also conjuring up the spectre of the Seven Deadly Sins (i.e. mirror, horses, garments - superbia; woman, bed - luxuria; treasure chest - avaricia; Sunday roast - gula). As a pictorial and mnemonic device this house of riches stands at the beginning of a long tradition of such architectural thesauri; these encompass both the tall, armoire-like edifices in the Good and Bad Prayers of Albertus Pictor and the richly appointed mansions which the devil conjures up for the dying man in the illustrated versions of the fifteenth-century Ars moriendi. ${ }^{22}$

While the Wismar mural thus anticipates later iconographical trends, artists elsewhere worked with different visual templates. Just how malleable the imagery was even at this early stage is suggested by a wall painting in the parish church of Søborg, located northwest of Copenhagen on the Danish island of Sjælland (cat. no. 33). Dating to c. 1400-1420, the image never appears to have featured an inventory of riches, nor indeed prayer lines, yet for all intents and purposes it still represents the theme of the Good and Bad Prayer, as two praying laymen, one bearded and older, the other clean-shaven and wearing a short tunic, face one another on the appropriate sides of the Crucified. A similar spiritual standoff is staged in a somewhat later version of the theme, a secco painting in the parish church of St Thomas at Nowe Miasto Lubawskie (Neumark) in western Prussia, in which the pious man is a pilgrim and the distracted man an aristocrat with an enormous fur hat (cat. no. 22). In contrast to Søborg, this mural of c. 1440-1450 also features a house of riches, which

22 On the illustrations of the Bilder-Ars, see Berndt Hamm, "Ars moriendi, Totenmemoria und Gregorsmesse: Neue Nahdimensionen des Heiligen im ausgehenden Mittelalter", Das Bild der Erscheinung: Die Gregorsmesse im Mittelalter, ed. by Andreas Gormans, Thomas Lentes, KultBild, 3; (Berlin: Reimer, 2007), 305-345, with further literature; the classic study on this material remains Clifton C. Olds, Ars moriendi: A Study of the Form and Content of Fifteenth-Century Illustrations of the Art of Dying, unpublished PhD dissertation (University of Pennsylvania, 1966). 


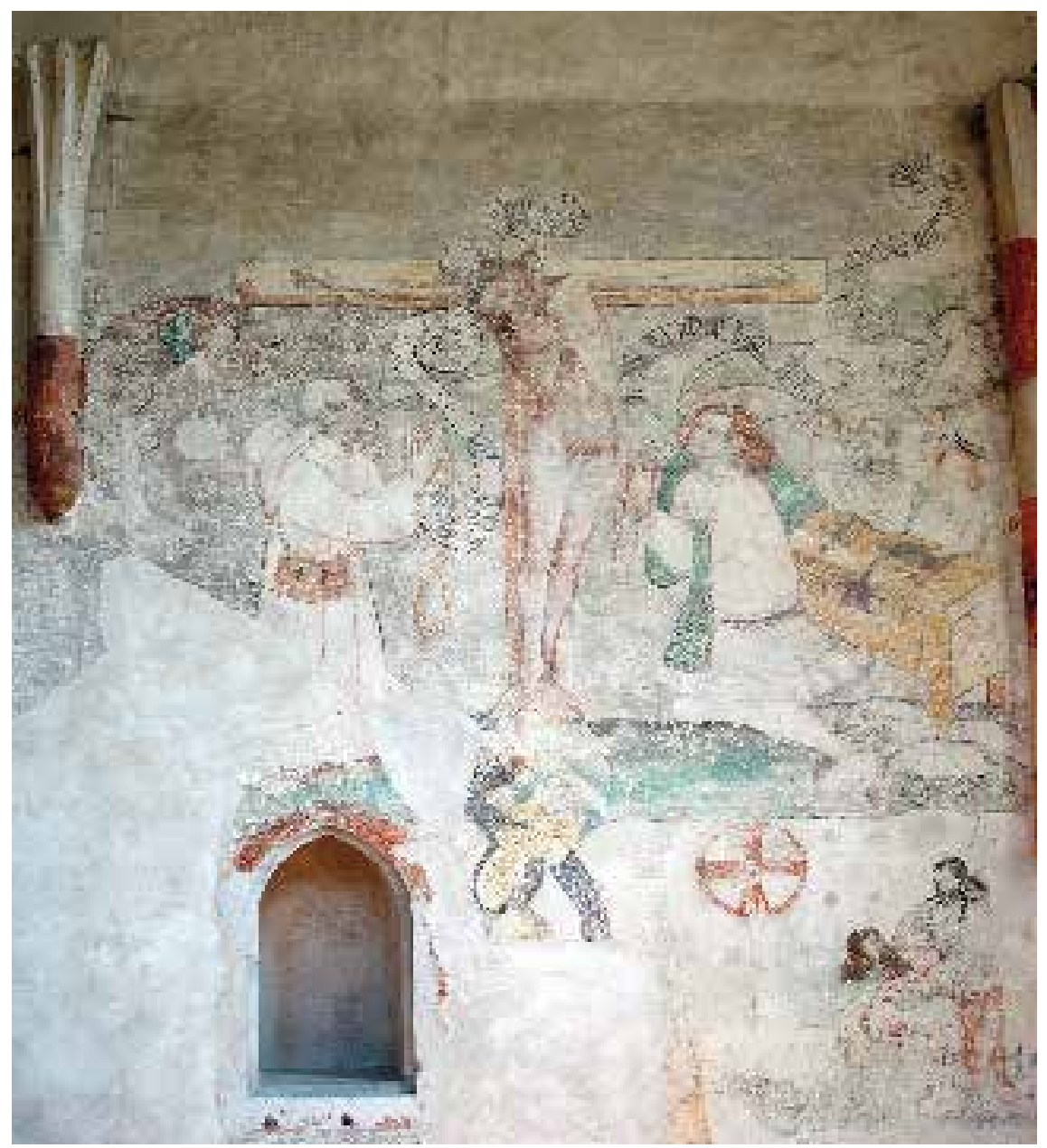

Fig. 4. Einbeck (Lower Saxony), Chapel of St Bartholomew, Good and Bad Prayer, c. 1430-1440

is depicted here as a crenellated castle rising from a rocky promontory perhaps a deliberate visual jibe against the unpopular Teutonic Knights, who finally lost their control over the town in 1454, when Neumark joined the Prussian Federation.

In the meanwhile, further inland in the Lower Saxon Duchy of Grubenhagen, the trustees of the Hospital of the Holy Spirit at Einbeck commissioned a Good and Bad Prayer for their leprosy chapel of St Bartholomew, located extra muros on the eastern outskirts of the town (fig. 4; cat. no. 5). Famous for its beer, Einbeck had joined the Hanse 


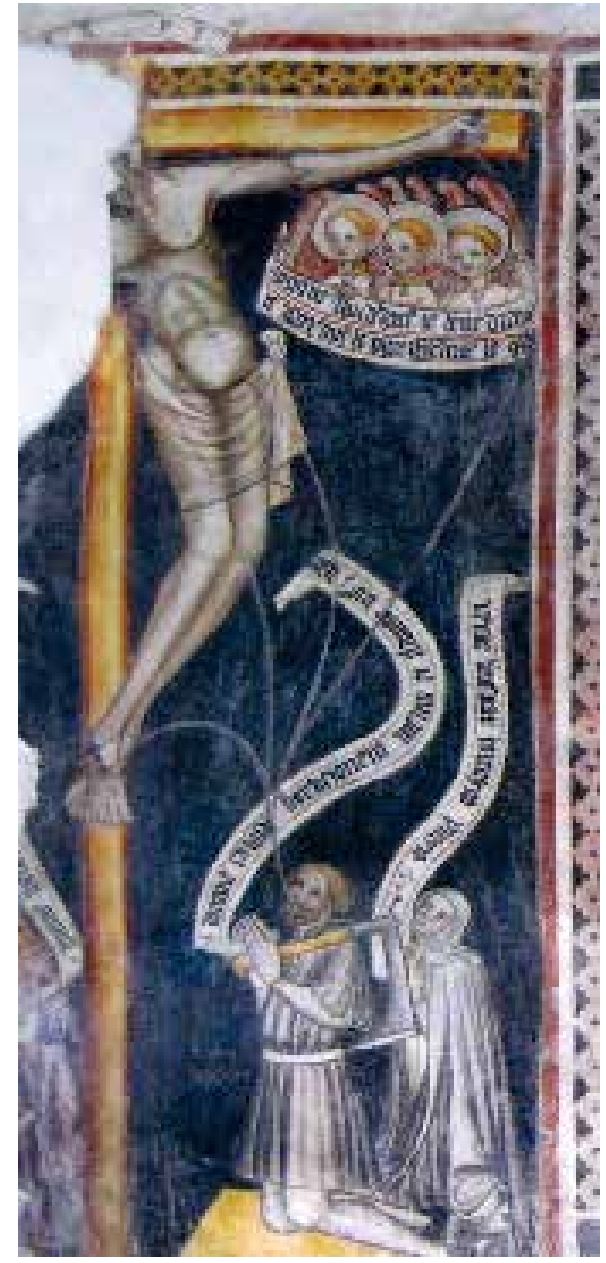

Fig. 5. Scena (South Tyrol), St George, Good and Bad Prayer, c. 1390-1400 in 1368 , a move that may unwittingly also have facilitated the exchange and transfer of artistic ideas. As at Nowe Miasto Lubawskie, the Einbeck mural, which dates to c. 14301440, depicts the pious man as a spiritual pilgrim while his opponent, a Judas-haired hoarder, is shown clamouring for ever-greater riches, as he rapaciously exclaims $d a$ mychi bona temporalia ("give me good temporal things"). In his delusional quest for bona temporalia (here various family members, livestock, and an enormous Stollentruhe with clamp-front construction), the rich man is aided by an airborne demon, who on his scroll knowingly quotes Matthew 6:21 Ubi thesaurus tuus ibi cor tuum ("For where thy treasure is, there is thy heart also"). It stands to reason that just as in the Heiligen-Geist-Hospital at Wismar this powerful rhetoric would not have been lost on the ailing, moribund viewers of the image, and after prolonged exposure one or the other may have felt sufficiently compelled to abandon his earthly cares and give generously toward the institution that sustained him through his last days.

We now turn southwards, towards the eastern Alps, where the theme of the Good and Bad Prayer had found a second foothold, and where, just as in the Hanseatic Kunstlandschaften, it was subject to constant experimentation. We can see this already in the earliest image of this group, a wall painting in the centralized parish church of St George at 
Scena (Schenna) in the Southern Tyrol, located about thirty kilometers northwest of Bolzano (fig. 5; cat. no. 31). The mural figures as part of a larger cycle of hagiographical scenes commissioned sometime around c. 1390-1400 from an anonymous artist now known as the Maestro di S. Giorgio. Rather unusually, the pious man, here with a carpenter's axe and accompanied by a veiled woman, appears on the sinister side of Christ, perhaps to indicate his state of humility. As his thick, vein-like thought lines attach themselves to the wounds of the Saviour, he mouths the words of the oratio pauperis ("Hear, O Lord my prayer: and let me cry come to thee"; Psalm 101:2), a passage that forms part both of the server's Confiteor at the beginning of Mass and of the Seven Penitential Psalms, prayed during Lent. ${ }^{23}$ Meanwhile, his female companion and the trio of angels above strike a more festive and anticipatory note, as they respectively recite a verse and a hymn from the Introit of Mass ("Come ye blessed of my Father", the words that Matthew 25:34 has Christ speak to the just souls on His right hand at the Last Judgment, and the Gloria in excelsis $\mathrm{deo}^{24}$ ). Aside from a fragmentary bearded figure the pictorial protagonists on the dexter side of the Crucified have been lost, so the question as to who (and what) complemented this fascinating tableau of simultaneous contrition and joyous foreknowledge must be left unanswered. Even though with its liturgical references the mural at Scena remained a non sequitur, one element of its design - the positioning of the pious man on the left side of Christ - was later taken up in several sixteenth-century versions of the theme, perhaps anticipating (and in one case echoing) the gradual reversal of the traditional dichotomy between right and left in the Reformation imagery of Lucas Cranach the Elder and his contemporaries (cat. nos. 1, 2, 10, 15, 20).

After fifty years or so the iconography of the Good and Bad Prayer surfaced both at Ortisei (St. Ulrich im Gröden), also in the Bolzano region of the South Tyrol (cat. no. 23), and further eastwards, at Ptuj (Pettau) in Lower Styria (cat. no. 26). The exceptional mural at Ortisei will be considered below; for now I wish to turn to the latter work, a wall painting of c. 1430-1440 in the nave of the parish church of St. George (fig. 6). The image makers were obviously faced with rather pressing hagiographical concerns (both the Virgin and the Evangelist John and a large figure of

23 Josef Andreas Jungmann, Missarum Sollemnia: Eine genetische Erklärung der Messe, 1 (Vienna: Herder, 1948), 363-365, 370-386.

24 Ibid., 398, with a discussion of the Introitus hymn at 397-412. 


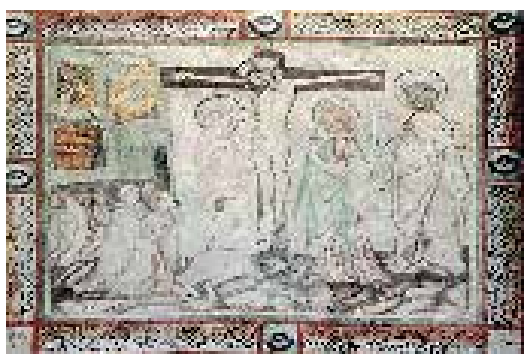

Fig. 6. Ptuj (Lower Styria), St George, Good and Bad Prayer, c. 1430-1440

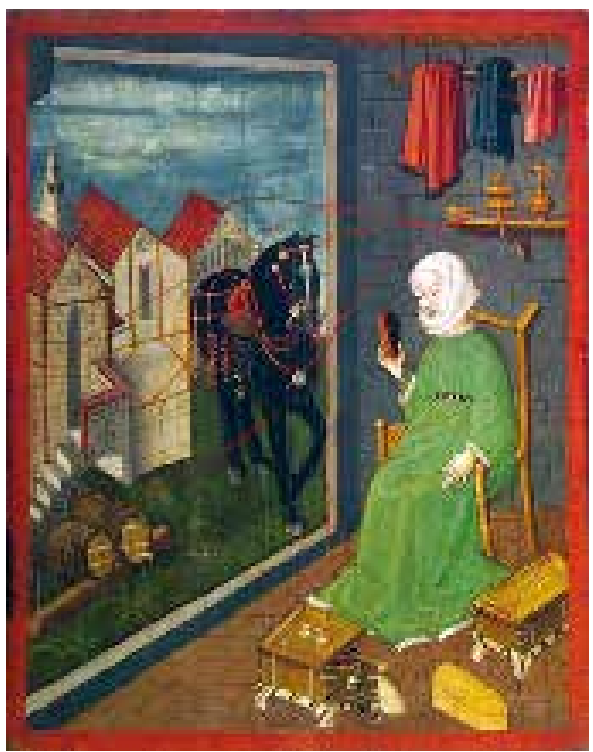

Fig. 7. Esztergom, Christian Museum, Good and Bad Prayer (fragment), 1430s

St. Peter also had to be accommodated), so all the elements that identify this representation as a Good and Bad Prayer were moved to the left side of the pictorial field. As a result, both the pious and the wayward man kneel below the dexter side of Christ, with the latter's worldly belongings being laid out for inspection just behind them. This thesaurus impresses both through the nature and the quantity of its hoard (a gated mansion, three horses, four wine barrels, a trunk crammed with moneybags), and it is complemented in the register below by a line-up of the rich man's entire family, five members in all. Just as the poor man would diligently say his multiple Paternosters and Hail Maries so would the self-indulgent man mull over, count and total the many things that tied him to this world, again and again.

No account of the early history of the Good and Bad Prayer would be complete without consideration of the three remarkable images which, like the Engelberg Psalter miniature, were destined for more select audiences. The first of these is a fragment of a didactic panel painting now in Esztergom, commissioned during the 1430s from an Austrian (or perhaps Hungarian) master and depicting, like the earlier mural at Wismar, a domestic setting with the 'thoughts' of the distracted man (fig. 7; cat. 


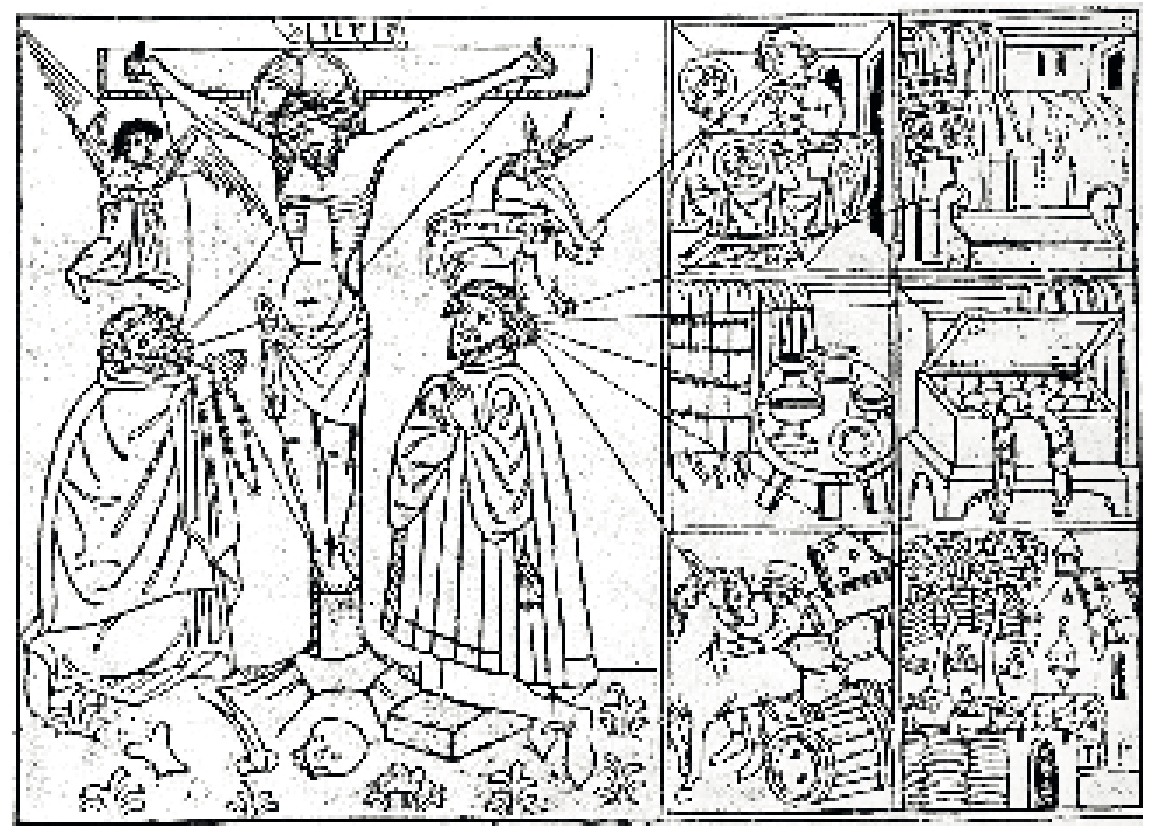

Fig. 8. Munich, Staatliche Graphische Sammlung, Good and Bad Prayer, c. 1430-1460

no. 8). Particularly striking are here the blood-red filaments that enter this house from the right, greedily probe its interior and adjacent courtyard, and eventually produce a series of subsidiary arteries that fasten themselves to an assortment of caskets and boxes in the foreground; one container has popped open, like an oyster, spilling forth precious things. We have already encountered some of the panel's tempting treasures in Wismar's Heiligen-Geist-Hospital, and they recur again, almost verbatim in a single-leaf woodcut produced sometime between c. 1430 and c. 1460 (fig. 8; cat. no. 21), where they are neatly arranged in six individual 'rooms' which the rich man sees and enters with his inner eye. In this, he receives aid from a demon 'tuning' his misguided thought lines, which are as taut as the strings of a violin. A similar tensile strength also flexes the imagination cords of the distracted man in the third image of this sequence (fig. 9; cat. no. 29), a drawing in a Miscellany from the second quarter of the fifteenth century (Rome, Biblioteca Casanatense, Ms. 1404), whose eclectic assemblage of allegorical representations, mystical diagrams, pagan gods and scenes from classical mythology and the Old 
Testament was studied by Fritz Saxl in two groundbreaking papers of 1927 and 1942. ${ }^{25}$ Depicted on fol. 2r (next to a Wheel of Fortune and a personification of superbia, a woman holding a mirror), this Good and Bad Prayer uniquely positions the two kneeling opponents on either side of a wayside shrine with the imago crucifixi; this arrangement places the viewer at a critical moral crossroads, where he or she must choose between the paths to heavenly and earthly treasures. Probably originating, like the Esztergom panel, in the south or southeast of the German-speaking lands, ${ }^{26}$ both the woodcut and the drawing from the Codex Casanatensis can serve here as stand-ins for the kinds of visual prototypes that may have been available to itinerant artists and that helped spread the Good and Bad Prayer first from the Kattegat to the Dolomites, and later, travelling in the baggage of Albertus Pictor and his peers, from the Maritime Alps to the southern Gulf of Bothnia.

In its visual conflation and conceptual accretion of axial cross, antithetical figures and various objects from the sphere of contemporary material culture (items of fashion, the rich man's thesaurus, as well as prayer aids such as rosaries and paternoster strings) the Good and Bad Prayer is in some ways a typical product of late medieval visual and allegorical thinking. What, more than anything else, sets this iconography apart both from the Crucifixion allegories of its time (for instance the

25 Fritz Saxl, "Aller Tugenden und Laster Abbildung”, Festschrift für Julius Schlosser zum 60. Geburtstage, ed. by Árpád Weixlgärtner, Leo Planiscig (Zürich: Amalthea, 1927), 104-121; idem, "A Spiritual Encyclopaedia of the Later Middle Ages", Journal of the Warburg and Courtauld Institutes, 5 (1942), 82-142; apart from two brief mentions the image of the Good and Bad Prayer receives no attention in these studies. Other iconographical aspects of the Casanatense manuscript are discussed in Peter Parshall, "The Art of Memory and the Passion", Art Bulletin, 81 (1999), 462-463; Almuth Seebohm, "The Crucified Monk", Journal of the Warburg and Courtauld Institutes, 59 (1996), 61-102, passim; Christian Kiening, Florian Eichberger, "Contemptus Mundi in Vers und Bild am Ende des Mittelalters", Zeitschrift für deutsches Altertum und deutsche Literatur, 123 (1994), 446-448; Lutz, Spiritualis fornicatio, 389-390.

26 The exact origins of the woodcut are unknown; at some stage the only extant copy was pasted into a collection of didactic and pastoral texts collated, perhaps still during the fifteenth century, in the Augustinian Monastery of Ranshofen, located near Braunau am Inn in Upper Austria. The Casanatense manuscript has been variously ascribed to a Silesian workshop (Saxl, A Spiritual Encylopaedia, 92) and, more generally, to a south German scriptorium (Parshall, "The Art of Memory“, 462). 


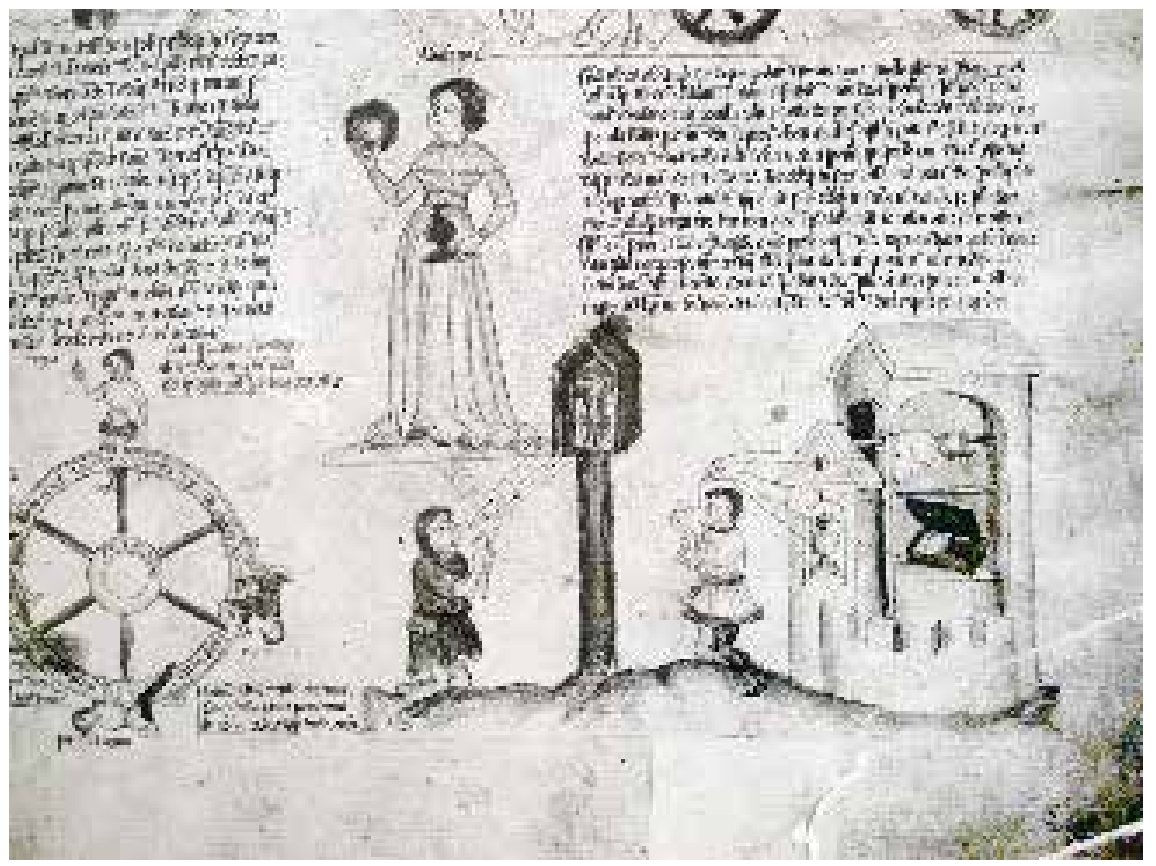

Fig. 9. Rome, Biblioteca Casanatense, Ms. 1404, fol. 2r, Good and Bad Prayer, c. 1425-1440

anti-Judaeic Living Cross ${ }^{27}$ or the pro-papal Ship of the $\mathrm{Church}^{28}$ ) and from other types of fourteenth- and fifteenth-century hortatory images

27 For the imagery of the Living Cross, see most recently Achim Timmermann, "Frau Venus, the Eucharist, and the Jews of Landshut", Judaism and Christian Art: Aesthetic Anxieties from the Catacombs to Colonialism, ed. by Herbert Kessler, David Nirenberg (Philadelphia, PA: University of Pennsylvania Press, 2011), 183-202; idem, “The Avenging Crucifix: Some Observations on the Iconography of the Living Cross“, Gesta, 40 (2001), 141-160; still fundamental remains Robert L. Füglister, Das lebende Kreuz: Ikonographisch-ikonologische Untersuchung der Herkunft und Entwicklung einer spätmittelalterlichen Bildidee und ihrer Verwurzelung im Wort (Einsiedeln: Benziger, 1964).

28 On this image, see Jochen Staebel, "Navis Ecclesiae Militantis: Zur Schiffsallegorie in der emanuelinischen Baukunst”, Re-Visionen: Zur Aktualität von Kunstgeschichte, ed. by Barbara Mikuda-Hüttel et al. (Berlin: Akademie-Verlag, 2001), 77-96; Ewald M. Vetter, "Das allegorische Relief Peter Dells d. Ä. im Germanischen Nationalmuseum”, Festschrift für Heinz Ladendorf, ed. by Peter Bloch, Gisela Zick (Cologne: Böhlau, 1970), 76-88; Ewald M. Vetter, "Sant peters schifflin", Kunst in Hessen und am Mittelrhein, 9 (1969), 7-34. 


\section{(e.g. representations of the Ten Commandments, ${ }^{29}$ the Seven Deadly Sins or of the Seven Works of Mercy $^{30}$ ) are the bundles of prayer-, thought-}

29 Late medieval imagery of the Decalogue is examined in Adam S. Labuda, "Kleidung als Bedeutungsträger: Zur Zehn-Gebote-Tafel aus der Marienkirche in Danzig", Bild-Geschichte: Festschrift für Horst Bredekamp, ed. by Philine Helas (Berlin: Akademie-Verlag, 2007), 413-430; Heimo Reinitzer, Gesetz und Evangelium: Über ein reformatorisches Bildthema, seine Tradition, Funktion und Wirkungsgeschichte, 2 vols (Hamburg: Christians Verlag, 2007), passim; Veronika Thum, "Die Zehn Gebote für die ungelehrten Leut': Der Dekalog in der Graphik des späten Mittelalters ud der frühen Neuzeit", Kunstwissenschaftliche Studien, 136 (Munich: Deutscher Kunstverlag, 2006); Klaus Biesenbach (ed.), Die Zehn Gebote: Eine Kunstausstellung, 19.Juni-5 .Dezember 2004, Deutsches Hygiene-Museum Dresden (Ostfildern-Ruit: Hatje Cantz, 2004); Olivier Christin, Les yeux pour le croire: les Dix Commandements en images, XVe-XVIIe siècle (Paris: Seuil, 1997); Ernst Murbach, "Die zehn Gebote als Wandbild: Ein Beitrag zur Darstellung des Dekaloges im späten Mittelalter", Unsere Kunstdenkmäler, 20 (1969), 225-230; Martin Lechner, "Zur Ikonographie der zehn Gebote: Fresken in Nonnberg, Landkreis Altötting”, Ostbairische Grenzmarken, 11 (1969), 313-339; Hans Vollmer, "Verdeutschung der Evangelien und sonstiger Teile des Neuen Testaments... nebst einem Anhang Deutsche Bilder zum Dekalog", Bibel und deutsche Kultur, 5 (Potsdam: Athenaion, 1935).

30 Studies on the Seven Deadly Sins have traditionally focused on Hieronymus Bosch's famous Tabletop in the Prado; recent scholarship on this imagery and its literary counterparts includes Magdalena Bushart, "Vom Diagramm zur Allegorie: Die Sieben Todsünden bei Hieronymus Bosch und Albrecht Altdorfer", Albrecht Altdorfer: Kunst als zweite Natur, ed. by Christoph Wagner, Oliver Jehle, Regensburger Studien zur Kunstgeschichte, 17 (Regensburg: Schnell \& Steiner, 2012), 291-301; Laurent Guitton, "Les sept péchés de Saint-Léry: allégorie infernale et conflits de pouvoir dans la Bretagne ducale au XVe siècle", Annales de Bretagne et des pays de l'Ouest, 118 (2011), 7-43; Thomas Lentes, "Der göttliche Blick: Hieronymus Boschs Todsündentafel; eine Einübung ins Sehen", Sehen und Sakralität in der Vormoderne, ed. by David Ganz, Thomas Lentes, KultBild, 4 (Berlin: Reimer, 2011), 20-61; Daniela Erlach (ed.), "Die sieben Todsünden in der Frühen Neuzeit", Frühneuzeit-Info, 21 (Vienna: Institut für die Erforschung der Frühen Neuzeit, 2010); Barbara Müller, "Die sieben Todsünden: Von der frühmonastischen Psychologie zur hochmittelalterlichen Volkstheologie", Lust und Laster: Die 7 Todsünden von Dürer bis Naumann, ed. by Maria Horst (Ostfildern: Hatje Cantz, 2010), 16-28; Christoph Flüeler (ed.), "Laster im Mittelalter; Vices in the Middle Ages", Scrinium Friburgense, 13 (Berlin: de Gruyter, 2009); Richard Newhauser (ed.), "The Seven Deadly Sins: From Communities to Individuals", Studies in Medieval and Reformation Traditions, 123 (Leiden: Brill, 2007); Michel Willemin, Les cavalcades des vices dans les Alpes Méridionales (Nice: Serre, 2006); Richard Newhauser (ed.), "In the Garden of Evil: The Vices and Culture in the Middle Ages", Papers in Mediaeval Studies, 18 (Toronto: Pontifical Institute of Medieval Studies Press, 2005); Carla Casagrande, Silvana Vecchio, "I sette vizi capitali: storia dei peccati nel Medioevo", Saggi, 832 (Turin: Einaudi, 2000). For the Seven Works of Mercy, which were often paired with the Seven Deadly Sins, see now David Griffith, "The Seven Works of Mercy in the Parish Church: The Development of a Vernacular Tradition", Patrons and Professionals in the Middle Ages: Proceedings of the 2010 Harlaxton Symposium, ed. by Paul Binski, Elizabeth A. New, Harlaxton Medieval Studies, 22 (Donington: Shaun Tyas, 2012), 292-315; Federico Botana, "The Works of Mercy in Italian Medieval Art (c. 1050 - c. 1400)“, Medieval Church Studies, 20 (Turnhout: Brepols, 2011); John R. Decker, "Civic Charity, Civic Virtue: The Master of Alkmaar's Seven Works of Mercy", The Sixteenth-Century Journal, 41 (2010), 3-28; Judith Niessen, "De Meester van Alkmaar en zijn werkplaats: een heroverweging", Oud-Holland, 123 (2010), 260-304; Wifredo Rincón Garcia, "La Charitas Cristiana en la iconografia medieval", Relegados al margen: marginlidad y espacios marginales en la cultura medieval, ed. by Inés Monteira Arias, Biblioteca de historia del arte, 12 (Madrid: CSIC Press, 2009), 199-209; Larry Silver, Henry Luttikhuizen, "The Quality of Mercy: Representations of Charity in Early Netherlandish Art", Studies in Iconography, 29 (2008), 216-248; Albert Dietl, "Vom Wort zum Bild der Werke der Barmherzigkeit: Eine Skizze zur Vor- und Frühgeschichte eines neuen Bildthemas", Schwelle zum Paradies: Die Galluspforte des Basler Münsters, ed. by Hans-Rudolf Meier, Stephan Albrecht (Basel: Schwabe, 2002), 74-93; but see also the relevant essays in Armut: Perspektiven in Kunst und Gesellschaft, ed. by Herbert Uerlings, Nina Trauth (Darmstadt: Primus Verlag, 2011), and Armut und Armenfürsorge in der italienischen Stadtkultur zwischen 13. und 16. Jahrhundert, ed. by Philine Helas, Gerhard Wolf (Frankfurt a. M.: Lang, 2006). 
or imagination lines that permanently tie the two praying men to the respective realms of their desires, in this world and the next. It is these vectors of ontological (and fatal) attraction that uniquely define the Good and Bad Prayer and make it so compelling, even after half a millennium. When the image was first devised in the early fourteenth century such lines were a relative novelty and primarily found in representations of the Stigmatization of St. Francis, where, of course, they were shown emanating from - rather than leading toward - the wounds of Christ. ${ }^{31} \mathrm{~A}$ century later, bundles of lines began to make their appearance in at least two other types of Christological representations, both of them entirely new and created and disseminated in tandem with a host of other pictorial inventions that premiered in the decades around 1400. The first of these was the Mass of St. Gregory or Gregorymass, in which clusters of 'blood lines' could on occasion leap from Christ's side wound (or the chalice) to provide succor to the Purgatorial dead (fig. 10). ${ }^{32}$ The second was the so-called Sunday Christ or Feiertagschristus, in which 'pain lines' converging on a central Man of Sorrows signal the disastrous effects of Sunday labour, dramatically implicating the viewer in a contemporary

31 For the iconography of the Stigmatization of St. Francis, see the recent studies by Paroma Chatterjee, "Francis's Secret Stigmata”, Art History, 35 (2012), 38-61; Carolyn Muessig, "The Stigmata Debate in Theology and Art in the Late Middle Ages", The Authority of the Word: Reflecting on Image and Text in Northern Europe, 1400-1700, ed. by Celeste Brusati et al., Intersections, 20 (Leiden: Brill, 2012), 481-504; Jesús Maria Parrado del Olmo, "La Estigmatización de San Francisco, de Alsonso Berruguete, y una pintura desaparecida de San Pietro in Montorio", Boletín del Seminario de Estudios de Arte y Arqueología, 77 (2011), 63-68; Arnold Davidson, "Miracles of Bodily Transformation, or How St. Francis Received the Stigmata”, Critical Inquiry, 35 (2009), 451-480; Bettine Menke, Barbara Vinken (eds.), Stigmata: Poetiken der Körperinschrift (Munich: Fink, 2004); Robert Kiely, "Further Consideration of the Holy Stigmata of St. Francis: where Was Brother Leo?", Religion and the Arts, 3 (1999), 20-40; Johan van Asperen de Boer, Jan van Eyck: Two Paintings of Saint Francis Receiving the Stigmata (Philadelphia, PA: Philadelphia Museum of Art, 1997); but see also David Ganz, "Gemalte Geheimnisse: Die Stigmatisierung Katharinas von Siena und ihre (Rück-)Übertragung ins Bild”, Medialität des Heils im späten Mittelalter, ed. Claudia Dauven-van Knippenberg, Medienwandel Medienwechsel - Medienwissen, 10 (Zürich: Cronos, 2009), 83-110.

32 For the image of the Gregorymass, which has elicited a considerable amount of recent scholarship, see now esp. David Ganz, Medien der Offenbarung: Visionsdarstellungen im Mittelalter (Berlin: Reimer, 2008); Andreas Gormans, Thomas Lentes (eds.), Das Bild der Erscheinung: Die Gregorsmesse im Mittelalter, KultBild, 3 (Berlin: Reimer, 2007); Gerhard Wolf, "Ananas und Tiara: Zur 'Gregorsmesse von Auch', Was aus dem Bild fällt: Figuren des Details in Kunst und Literatur, ed. by Edith Futscher et al. (Munich: Fink, 2007), 333-347; Esther Meier, Die Gregorsmesse: Funktionen eines spätmittelalterlichen Bildtypus (Cologne: Böhlau, 2006); Caroline Walker Bynum, "Seeing and Seeing Beyond: The Mass of St. Gregory in the Fifteenth Century", The Mind's Eye: Art and Theological Argument in the Middle Ages, ed. by Jeffrey F. Hamburger, Anne-Marie Bouché (Princeton: Princeton University Press, 2006), 208-240; Heike Schlie, "Die Autoritätsmuster der 'Gregorsmesse': Umdeutungen und Auflösungen eines Zeichensystems", Das Bild als Autorität: Die nominierende Kraft des Bildes, Pluralisierung \& Autorität, 4, ed. by Frank Büttner, Gabriele Wimböck, (Münster: LIT, 2004), 73-101. 


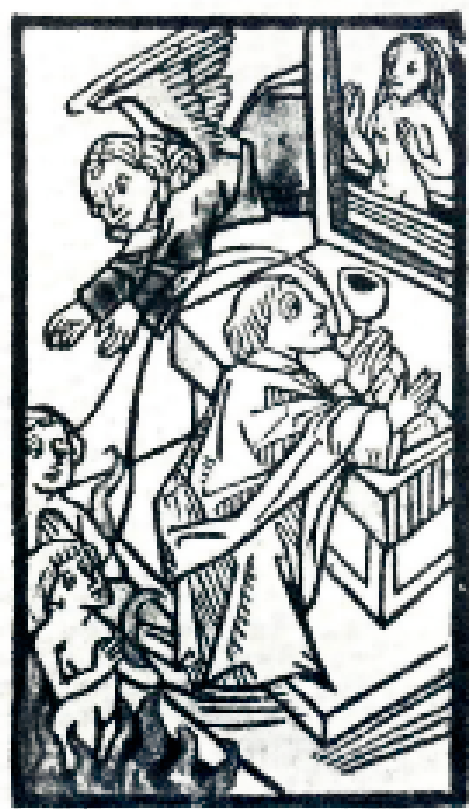

Fig. 10. Washington, National Gallery, Mass of St Gregory, c. 1460

version of the Passion story. ${ }^{33}$ In the Good and Bad Prayer, this versatile pictorial device was reconfigured once again, with the lines now representing and projecting thoughts, imaginings, and yearnings, and giving visual form to that which only the inner gaze can truly perceive.

During the course of the fifteenth century these constant experiments in visual and semantic condensation and extrapolation brought forth a series of intriguing crossovers, in which one iconography (or a significant element thereof) was grafted onto the matrix of another, often while retaining a central armature (such as the body of Christ) that was common to both images. Among these amalgamations an exterior mural on the parish church of Ortisei in the South Tyrol of c. 1452-1460 takes pride of place (fig. 11; cat. no. 23). Partially painted over in the eighteenth century with one of the Stations of the Cross, the image represents a unique fusion between a Sunday Christ and a Good and Bad Prayer. A

33 For the Sunday Christ, see now in particular Alberto Zaina, "Il precetto festivo tra ammonizione e devozione: Il 'Cristo della domenica' negli affreschi breschiani”, Brixia sacra, 13 (2008), 33-63; Dominique Rigaux, Le Christ du dimanche: histoire d'une image médiévale (Paris: L'Harmattan, 2005); Athene Reiss, The Sunday Christ: Sabbatarianism in English Medieval Wall Painting (Oxford: Archaeopress, 2000). 


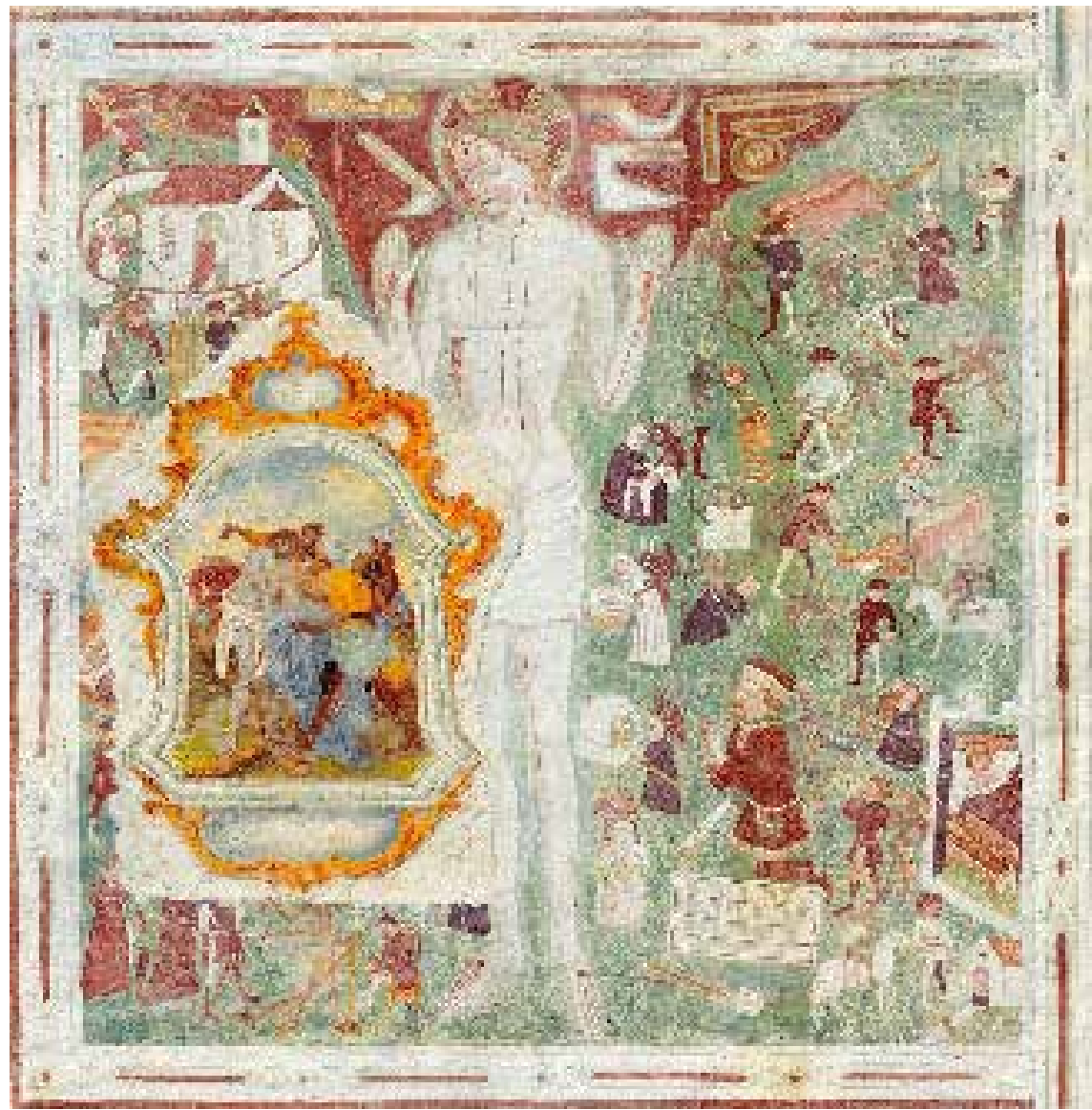

Fig. 11. Ortisei (South Tyrol), parish church, Sunday Christ with Good and Bad Prayer, c. $1452-1460$

ghostly pale, orant Man of Sorrows is literally enmeshed here in an arterial network of human wrongdoings (in the guise of pictograms and narrative miniatures generating red lines) and of opposing depictions of piety and worldliness (traceable through white lines). Of the latter, only the rich man with his crenellated house of treasures (containing his wife, bed and money chest) has survived - vain belongings all which, as the accompanying inscription helpfully explains, he "has not won at all" ("sein gut das mit-nichten gwunen ist").

The iconographical revolution that was to bring the Good and Bad Prayer to international prominence unfolded just as the Roman Church was fighting one of its fiercest battles yet, tackling both the crippling 
effects of the Great Schism and the growing threat from the radical Bohemian Hussites and other heresies. Conciliarism was one response to this crisis, a general spiritual overhaul (reformatio personalis) of her congregation another. During the early decades of the fifteenth century various men of the Church, including Jean Gerson, Johannes Nider and Nikolaus von Dinkelsbühl, embarked on an ambitious programme of pastoral reform which was aimed both at reinforcing orthodox beliefs and practices and at improving the religious education and welfare of laypeople. ${ }^{34}$ Even though it originated in the earlier fourteenth century, the Good and Bad Prayer was ideally suited to giving visual expression to some of the chief concerns of the reformist movement.

First and foremost, the image was about the contrast between spiritual wealth and material poverty on the one hand and material wealth and spiritual poverty on the other, ${ }^{35}$ its primary aim was to instill in its viewers a yearning for contemptus mundi and a simultaneous hatred of amor mundi. Perhaps not entirely surprisingly, artists, no doubt in conversation with their clerical advisors, lavished much of their didactic imagination on the representation of the latter, the visible and tangible world of things, which often occupied a considerable portion of a given composition. To contemporary audiences these panoplies of alluring objects would have taken on an added significance if read against the backdrop of sumptuary laws and the fiery sermons of reformist preachers. Witness, for instance, Nikolaus von Dinkelsbühl, who in his homily "On Abundance and on Want" thundered against a worldly person's

34 For the late fourteenth- and fifteenth-century Church Reform and the activities of its principal supporters, see now Brian Patrick McGuire (ed.), A Companion to Jean Gerson (Leiden: Brill, 2006); Brian Patrick McGuire, Jean Gerson and the Last Medieval Reformation (University Park, PA: Pennsylvania State University Press, 2005); Birgit Studt, Papst Martin V. (1417-1431) und die Kirchenreform in Deutschland (Cologne: Böhlau, 2004); Nikolaus Staubach (ed.), Kirchenreform von unten: Gerhard Zerbolt von Zutphen und die Brüder vom gemeinsamen Leben (Frankfurt a. M.: Lang, 2004); Michael David Bailey, Battling Demons: Witchcraft, Heresy, and Reform in the Late Middle Ages (University Park, PA: Pennsylvania State University Press, 2003); Jürgen Miethke, Lorenz Weinrich (eds.), Quellen zur Kirchenreform im Zeitalter der grossen Konzilien des 15. Jahrhunderts, 3 vols (Darmstadt: Wissenschaftliche Buchgesellschaft, 1995-2004).

35 On the conflicting medieval notions of wealth, see the recent collection of essays "Les élites et la richesse au Moyen Âge", Collection Haut Moyen Âge, 10, ed. by Jean-Pierre Devroey, Laurent Feller, Régine Le Jan (Turnhout: Brepols, 2010); various aspects of medieval poverty are discussed in Anne M. Scott, Experiences of Poverty in Late Medieval and Early Modern England and France (Farnham: Ashgate, 2012); Kate Crassons, The Claims of Poverty: Literature, Culture, and Ideology in Late Medieval England (Notre Dame, IN: University of Notre Dame Press, 2010); Dinah Hazell, Poverty in Late Medieval English Literature: The Meene and the Riche (Dublin \& Portland, OR: Four Courts Press, 2009); Sharon Farmer, Surviving Poverty in Medieval Paris: Gender, Ideology, and the Daily Lives of the Poor (London \& Ithaca, NY: Cornell University Press, 2002). 
"many servants, costly garments, large silver belt, tall and broad stone houses, many gold buttons... tall, well bred horses, abundant food and drink and other such things, which make a man not honorable". ${ }^{36}$

These diatribes against fifteenth-century commodity fetishism famously culminated in the penitential sermons of the Observant Franciscan friar Giovanni da Capistrano, Church reformer, papal envoy and dreaded "Scourge of the Jews"; wherever he preached, all across the Holy Roman Empire, great bonfires were lit to consume the vanities of the world. Chroniclers recording his preaching activities in Nuremberg in 1452 were awestruck by the high shooting flames that left a strange blue haze over the Reichsstadt, and which reduced to ashes, so they claimed, cartloads of plumed hats, doublets with slashed sleeves, pointed shoes, headdresses as well as three thousand checkerboards and forty thousand dice sets. Likening the rich, impenitent and vainglorious to moles

36 "Erwirdichait oder erberchait der person sein tugent und guete werck, darumb wann vil chnecht, schon gewant, grosz silber gürtel, hoch und weit stain hewsser, vil guldeiner knoppff... hoch schone rosz, wol essen und trincken und derlay machete den menschen nicht eren wert." Quoted after Jaritz, "Das schlechte Gebet", 86, who in turn cites Ernst Englisch, "Materialien zur Lebenshaltung aus Wiener religiöser Literatur des späten Mittelalters", Das Leben in der Stadt des Spätmittelalters: Internationaler Kongress Krems an der Donau 20. bis 23. September 1976, ed. by Heinrich Appelt, Sitzungsberiche der Österreichischen Akademie der Wissenschaften, philosophisch-historische Klasse, 325 (Vienna: Verlag der Österreichischen Akademie der Wissenschaften, 1980), 155. Fuelled by an academic and archaeological turn toward the everyday, the study of the kinds of objects that Nikolaus von Dinkelsbühl targets - of how they were acquired, used, touched, held, admired, enjoyed and how they shaped the experience of quotidian materiality - has become a virtual cottage industry over the past twenty-five or so years, producing a plethora of conferences, exhibitions, monographs and specialized journals. Recent publications with particular relevance to the types of late medieval objects touched on in this study include the following: Roberta Gilchrist, Medieval Life: Archaeology and the Life Course (Woodbridge: Boydell, 2012); Tara Hamling, Catherine Richardson (eds.), Everyday Objects: Medieval and Early Modern Material Culture and its Meanings, (Farnham \& Burlington, VT: Ashgate, 2010); Margaret Burland, David LaGuardia, Andrea Tarnowski (eds.), "Meaning and Its Objects: Material Culture in Medieval and Renaissance France," Yale French Studies, 110 (New Haven \& London: Yale University Press, 2006); Jerzy Piekalski, Krzysztof Wachowski (eds.), "Wrocław na przełomie średniowiecza i czasów nowożytnych: Materialne przejawy życia codziennego", Wratislavia Antiqua, 6 (Wrocław: Uniwersytet Wrocławski, 2004); Curtis Perry (ed.), "Material Culture and Cultural Materialisms in the Middle Ages and Renaissance", Arizona Studies in the Middle Ages and Renaissance, 5 (Turnhout: Brepols, 2001); Malcolm Vale, The Princely Court: Medieval Courts and Culture in North-West Europe, 1270-1380 (Oxford: Oxford University Press, 2001); Gerhard Jaritz (ed.), "Pictura quasi fictura: Die Rolle des Bildes in der Erforschung von Alltag und Sachkultur des Mittelalters und der frühen Neuzeit", Forschungen des Instituts für Realienkunde des Mittelalters und der Frühen Neruzeit; Diskussionen und Materialien, 1 (Vienna: Verlag der Österreichischen Akademie der Wissenschaften, 1999); Helmut Hundsbichler, Gerhard Jaritz, Thomas Kühtreiber (eds.), "Die Vielfalt der Dinge: Neue Wege zur Analyse mittelalterlicher Sachkultur; Gedenkschrift in memoriam Harry Kühnel”, Forschungen des Instituts für Realienkunde des Mittelalters und der Frühen Neuzeit; Diskussionen und Materialien, 3 (Vienna: Verlag der Österreichischen Akademie der Wissenschaften, 1998); Guy De Boes, Frans Verhaege (eds.), Material Culture in Medieval Europe: Papers of the 'Medieval Brugge 1997’ Conference (Zellik: Instituut voor het Archeologisch Patrimonium, 1997). 
whose eyes are covered with a membrane that breaks only at death, Capistrano frequently used actual skulls in his frightening memento mori performances, crying out to his audiences, "Here is your mirror. Look in and see your reflection. Where is that nose that inhaled such pleasing odours? Where is that hair that once delighted you? Where is that tongue that slandered? Worms have devoured all." ${ }^{\prime 37}$

As a meditation on the vanities of the world and on true poverty the Good and Bad Prayer provided, perhaps sometimes unwittingly, an appropriate visual gloss on the social drama of sermons and bonfires. To tease out the eventual implications of the stark choices made by its pictorial actors, the image could on occasion include additional elements drawn from biblical, exegetical or even poetic sources. On a panel painted in an Upper Rhenish workshop in 1474 (fig. 12; cat. no. 35) the antithesis between the stigmata-gazing ascetic and the foppish, fur-wearing and fun-loving squanderer is meaningfully enriched through narrative details from the Parable of Lazarus and Dives, which contemporary viewers would have been familiar with from both the original account given in Luke 16:19-25 and from later medieval adaptations such as the Middle English Dives and Pauper of c. 1405-1410. ${ }^{38}$ The rich man's towering house of treasures is complemented here by its biblical 'twin', the mansion of Dives, in which a banquet is in full swing while in the courtyard below dogs lick the sores of the hapless Lazarus. As both men breathe their last - Dives in his soft bed, Lazarus on the hard, bare earth - their fates are reversed, with the pauper's soul being subsumed into Abraham's bosom and the rich man's anima swallowed by the chomping fangs of the Maw of Hell. In a further moralizing twist, Death himself materializes at the bottom of the panel (here as a cadaverous, worm-eaten skeleton that would no doubt have found the approval of the dire Capistrano), and urges his viewers to leave behind their sinful lives as they confront the certainty of death and, at the same time, the uncertainty of the hour of death ("O mentsch folg miner ler / diech von dinen sünden Kör / du must sterben das waist du woll / und waist doch nit wenn das geschehen soll").

37 Based on Richard Wunderli, Peasant Fires: The Drummer of Niklashausen (Bloomington, IN: Indiana University Press, 1992), 42-43.

38 See the magisterial edition by Priscilla Heath Barnum, Dives and Pauper, 2 vols (London: Oxford University Press for the Early English Text Society, 1976-2004), with further literature; see also Hazell, Poverty in Late Medieval English Literature. 


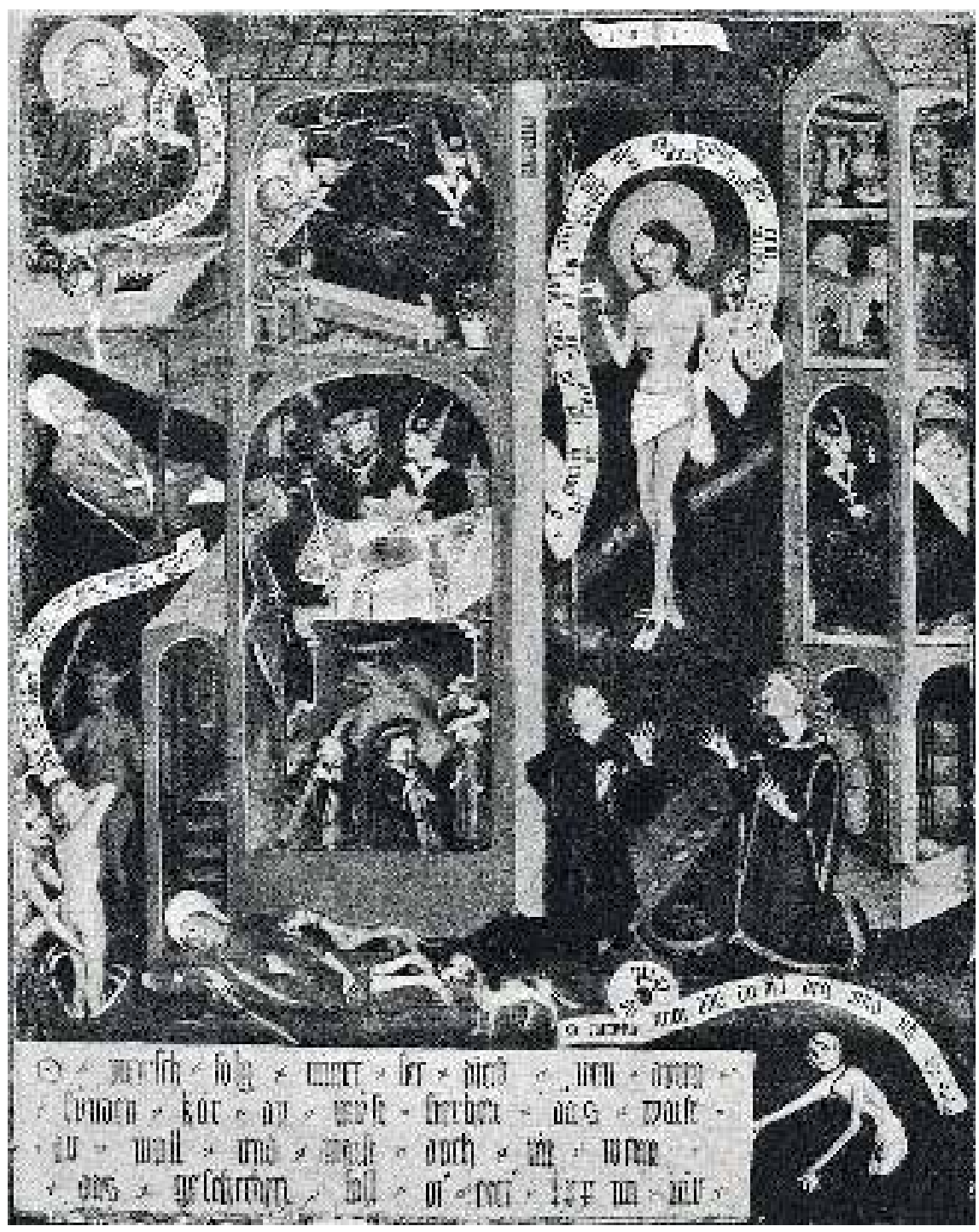

Fig. 12. Strasbourg, Musée de l'OEuvre de Notre Dame, Good and Bad Prayer with Parable of Lazarus and Dives, 1474

While the iconography of the Good and Bad Prayer appears to have been primarily calibrated to articulate and frame this very existential choice between two competing economies, the worldly and the spiritual, in the second instance the image also brings into focus the culture of (lay) prayer, which underwent a fundamental transformation during 
later Middle Ages. Perhaps the most significant change was a gradual shift from various forms of collective, liturgical prayer to a more private, personalized praying experience; advocated by pastoral theologians such as Jean Gerson and Nicolas de Clamanges this shift was in part occasioned by the very real observation that liturgical situations often encouraged patterns of worship that were purely extrinsic, while at the same time devotions performed outside public celebrations led to a far greater correspondence between mind and spirit. Provisions for the latter could of course not always be made, so some catechetical manuals furnished detailed instructions as to how to achieve a perfect equilibrium between one's exterior and interior person even during liturgical performances, for instance by following a certain dress code (removing one's shoes and hat), bending the knees and holding the palms together in the direction of God, all while attentively concentrating one's mind on a few simple, but effective maxims (e. g. not to seek gold and silver in prayer but spiritual understanding to do God's will, to continually call on God with a humble heart, and so forth). ${ }^{39}$

The pious man in the Good and Bad Prayer in many ways represents the perfect embodiment of these prescriptions. On the one hand, his recurrently emaciated or unkempt appearance and attire (plain, sometimes torn, with often discalced feet, and / or wearing pilgrim's garb) suggest a life of abject poverty, self-deprivation and physical self-negligence, spent well away from the materialist pettiness of the world in great humility before, and in constant search of, God. On the other hand, the cords that connect him to the wounds of the Saviour indicate that he has indeed reached the end of his journey, and that soon he will perceive behind those stigmata a dimension of the heavenly that - in contrast to the rich man's thesaurus - eludes visual representation. One of the most poignant depictions of this proximity to Christ can be found at Einbeck (fig. 4; cat. no. 5), where the pious man, here wearing the cus-

39 Aldrin, The Prayer Life, 54, 68. On later medieval cultures of (especially lay) prayer, see also Virginia Reinburg, French Books of Hours: Making an Archive of Prayer, c. 1400-1600 (Cambridge: Cambridge University Press, 2012); Niklaus Largier, "Inner Senses - Outer Senses: The Practice of Emotions in Medieval Mysticism", Codierung von Emotionen im Mittelalter, ed. by C. Stephen Jaeger, Ingrid Carsten, Trends in Medieval Philology, 1 (Berlin: de Gruyter, 2003), 3-15; Nicole Bériou, Prier au Moyen Âge: Pratiques et experiences (Ve-Xve siècles) (Turnhout: Brepols, 1991); Timothy Johnson, "Iste Pauper Clamavit: Saint Bonaventure's Mendicant Theology of Prayer", European University Studies, ser. XXIII: Theology, 390 (Frankfurt, Bern, New York \& Paris: Lang, 1990), and the relevant sections in Duncan Robertson, Lectio divina: The Medieval Experience of Reading (Collegeville, MN: Cistercian Publications, 2011). 
tomary pilgrim's hat and bag, is joined by a censing angel emerging from a celestial cloud; even more importantly, this seeker of God makes his supplication directly above the tabernacle for the consecrated sacrament, that mystical hagioscope through which the thesaurus in caelo could be glimpsed here on earth. In my last example, a mural in the parish church of Härnevi near Västerås, painted c. 1470-1480 by the great Albertus Pictor himself, Christ's redemptive blood has been accorded a positively nourishing role (fig. 1; cat. no. 14). In an iconographic 'double take', the artist has overlaid the image of the Good and Bad Prayer with that of a Gregorymass, substituting the Crucified Christ with the Man of Sorrows surrounded by the arma Christi and a chalice catching His blood. This visual palimpsest effectively turns the pious, barefooted man into a lay counterpart of Pope Gregory who here is being granted his own miraculous and private Gottesschau. It could also be argued that in this representation Christ uniquely reciprocates the humble, pure-hearted prayer of the poor man ("Have mercy on me, O God, according to thy great mercy"; Psalm 50:3), as the cords that connect His stigmata with the sacramental chalice also seemingly reverse the flow of the prayer lines, initiating a kind of 'double transfusion' of salvific cruor. While the rich man remains locked within the gravitational field of the world of material excess, the pauper, sustained and buoyed by Christ's blood, is headed to that other world, "where neither the rust nor moth doth consume, and where thieves do not break through, nor steal".

Whether the viewers for whom this image was initially made were won over by its uplifting pictorial rhetoric or whether indeed they still preferred to throw in their lot with the rich man, with his enviable fittings, furnishings and fripperies, is a question worth asking. Even though a more precise answer will probably forever elude us, one suspects that the churchgoers at Härnevi and in parishes elsewhere might have opted for the middle path, conscientiously prayed their Paternosters, perhaps nudis pedibus, while secretly admiring and coveting the brocaded robe of a nobleman they themselves could not afford to buy. To their great vexation the proponents of the pastoral reform - preachers, liturgists, image-makers - might have discovered that serving both "God and mammon" (Matthew 19:24) was in fact an all too human thing to do. 


\section{A PRELIMINARY CATALOGUE}

This catalogue contains forty-one surviving or documented representations of the Good and Bad Prayer known to me at the time of writing (June 2013). It comprises 32 wall paintings, four panel paintings, two manuscript miniatures, two prints (woodcut, engraving), and one example of polychromed sculpture. 22 of the images are found in Scandinavia (14 in Sweden, seven in Denmark, one in Finland), 13 are located or originated in the former Holy Roman Empire and its adjacent territories (Germany, Austria, Poland, Hungary), two were produced in the Netherlands, two in the former Duchy of Savoy (now part of France), one in Switzerland and one in Italy. The vast majority of the depictions, 23 in total, were created between c. 1450 - c. 1510, seven were executed between c. 1400 - c. 1450 , five between c. 1510 - c. 1530 , three between c. 1330 - c. 1400 , and another three between c. 1530 - c. 1570. Unless otherwise specified in the catalogue, all images are in the medium of wall painting.

\section{1. Åstrup (island of Falster, Denmark), parish church, c. 1500 \\ Location: Nave, $n$. vault. \\ Christ: Man of Sorrows.}

Praying figures: Traditional positions reversed; young, long-haired man with belted dagger and short, pleated tunic on dexter side of Christ; older, bearded man with pilgrim's attributes, nudis pedibus, on His sinister side; both with rosaries.

Inventory of riches: On right, behind rich man; closed treasure chest, wine barrels, female cook preparing meal over fire.

Iconographic context: Evangelist symbols, Fall and Expulsion, Labours of Adam and Eve.

Hammer, Sakrale Wandmalerei in Dänemark, 181; Ulla Haastrup (ed.), Danske kalkmalerier: Sengotik, 1500-1536 (Copenhagen: Nationalmuseet, 1992), 263, with further literature; Søren Kaspersen, "WallPaintings and Devotion: The Impact of Late Medieval Piety on Danish Murals", Images of Cult and Devotion: Function and Perception of Christian Images in Medieval and Post-Medieval Europe, ed. by Søren Kaspersen, Ulla Haastrup (Copenhagen: Museum Tusculanum Press, 2004), 207. 
2. Breda (Noort-Brabant, Netherlands), Onze-Lieve-Vrouwekerk, c. 1530-1566

Location: Nave, s. side, Niervaartkapel.

Christ: Crucified, inscription below cross super habundantia caritas est causa mortis cristi.

Praying figures: Clean-shaven man in fur-lined robe on dexter side of Christ; veiled woman in long, dark attire (nun?) on His sinister side; both figures middle-aged.

Inventory of riches: Four-storied 'house', on left, behind man, its interior spaces revealing, from top to bottom, open treasure chest and various commodities, grain sacks and wine barrels, pasture landscape with haystacks, and exterior of large house.

Iconographic context: Independent mural.

J. G. van Gelder, "Een aanvulling in margine”, Oudheidkundig Jaarboek, 9-11 (1939); Por, "Een merkwaardige schildering”, 37-44; Wisselaar, "Evagationes spiritus"; Gerard Van Wezel, De OnzeLieve-Vrouwekerk en de grafkapel voor Oranje-Nassau te Breda, De nederlandse monumenten van geschiedenis en kunst, 40 (Zeist \& Zwolle: Rijksdienst voor de Monumentenzorg, 2003), 289-292.

\section{Danmark (Uppland, Sweden), parish church, c. 1490, Albertus Pictor} The image is combined with a Mass of St. Gregory, substituting the Crucified with the Man of Sorrows. It is located on the south wall of the nave and appears in conjunction with the Legend of St. Olav, the Church Fathers, the Fall and Expulsion, and a Salvator mundi. No reproduction was available to me at the time of writing.

Henrik Cornell, Sigurd Wallin, Uppsvenska målarskolor på 1400-talet (Stockholm: s. n., 1933), 124; Cornell, Albertus Pictor, 89; Nilsén, Program och function, 62.

\section{Dannemora (Uppland, Sweden), St. John the Baptist, c. 1500}

Location: Porch, w. wall.

Christ: Man of Sorrows with arma Christi and chalice, standing on altar. Praying men: Older, bearded man wearing hooded cloak, nudis pedibus, on dexter side of Christ; younger, clean-shaven man with long hair and red mantle over white robe on His sinister side, wearing galoshes; both with rosaries. 
Inventory of riches: Two-storied house, with scenes of woman with mirror before rack of sumptuous garments, servant inspecting open treasure chest, groom with bridled horse.

Iconographic context: Wheel of Fortune, Lazarus and Dives.

Nilsén, Program och function, 65; Melin, Fåfängans förgänglighet, 123, Aldrin, The Prayer Life, 83.

\author{
5. Einbeck (Niedersachsen, Germany), Chapel of St Bartholomew, \\ c. 1430-1440 (fig. 4) \\ Location: Choir, n. wall. \\ Christ: Crucified.
}

Praying figures: Older, bearded man wearing pilgrims attire on dexter side of Christ, with angel above (scroll illegible); younger, clean-shaven man with long, red hair, wearing belted tunic and pointed shoes on His sinister side (scroll D[omi]ne Jh[es]u da mychi bona temporalia), with devil to left of patibulum (scroll Ubi thesaurus tuu[s] ibi cor tuum).

Inventory of riches: Wife with child, daughter (or mistress?), large treasure chest, horse and two pigs.

Iconographic context: Independent image, painted above sacrament niche and later representations of St. George and the Doubting Thomas.

Wildhaber, "Das gute und das schlechte Gebet, 69; Erich Plümer", "Die spätgotischen Wandmalereien in der Bartholomäus-Kapelle zu Einbeck", Einbecker Jahrbuch, 29 (1970), 104-115; Kretzenbacher, "Ein Innviertler Mahnbild-Fresko", 122; Horst Huelse (ed.), Die Inschriften der Stadt Einbeck, Die deutschen Inschriften, 42 (Wiesbaden: Reichert, 1996), 26-27; Andreas Heege, Einbeck im Mittelalter: Eine archäologisch-historische Spurensuche (Oldenburg: Isensee, 2002), 105.

\title{
6. Elmelunde (Island of Møn, Denmark), parish church, 1499-1507
}

Location: Nave, e. vault.

Christ: Crucified.

Praying figures: Older, bearded man wearing long cloak and worn shoes on dexter side of Christ (scroll Deus [prop]ici[u]s esto mihi peccatori); young man wearing short, fur-lined tunic and pointed shoes on His sinister side (scroll Miserere mei deus); both with rosaries.

Inventory of riches: Two-storied house with tower, sumptuous garments on T-shaped rack, bridled horse. 
Iconographic context: Creation of Adam and Eve, Fall and Expulsion, Labours of Adam and Eve.

Hammer, Sakrale Wandmalerei in Dänemark, 168; Haastrup (ed.), Danske kalkmalerier: Sengotik, 59, 246-247, with further literature; Kaspersen, "Wall-Paintings and Devotion", 207; Jaritz, "Das schlechte Gebet", 87.

\section{Engelberg (Switzerland), Stiftsbibliothek, Latin Psalter Cod. 62, c. 1330, Swiss illuminator (fig. 2)}

Location: fol. $17 \mathrm{r}$, opposite a miniature of the Throne of Solomon on fol. 16v.

Christ: Crucified.

Praying figures: Older, bearded man, nudis pedibus, on Christ's dexter side; younger man with long-sleeved mantle over hooded robe, wearing buckled shoes, on His sinister side.

Inventory of riches: In bottom half of image; costly vessels on display, horse grazing on meadow with groom, servant moving barrel with rope, servant carrying a money- or grain-bag up (or down) flight of stairs. Iconographic context: Infancy and Passion of Christ (with Christ Crucified by Virtues on fol. 12v), Throne of Solomon, Ascension of John the Evangelist, Second Coming of Christ, Throne of Mercy.

Marti, Malen, Schreiben und Beten, 48, 213-214, 266.

\section{Esztergom (Hungary), Keresztény Múzeum; panel painting, 1430s, Austrian or Hungarian workshop (fig. 7)}

Fragment; only right portion of image without Christ survives.

The fragment depicts the object(s) of the (lost) distracted figure's thoughts: the interior of a house, in which a seated woman admires herself in a mirror; around her are arranged three treasure chests, a rack of sumptuous garments and a shelf with golden tableware; to her right is an open courtyard with outbuildings, containing two beer- or wine-barrels and a richly caparisoned horse.

\footnotetext{
Pigler, "Evagationes spiritus"; De Tervarent, "En marge du catalogue”, 59-60; András Mucsi, Gothic and Renaissance Panel Paintings in the Esztergom Christian Museum (Esztergom: Christian Museum, 1990), 7-8; Pál Cséfalvay (ed.), Christian Museum Esztergom (Budapest: Corvina, 1993), 188; Kretzenbacher, "Drei altösterreichische Mahnbild-Zeugnisse", 131-134; Jaritz, "Ira Dei, Material Culture", 54; Jaritz, "Das schlechte Gebet", 91-93.
} 
9. Everlöv (Skåne, Sweden), parish church, c. 1500

Fragmentary, lower portion of figures obliterated.

Location: Nave, nw. vault.

Christ: Man of Sorrows.

Praying figures: Older, bearded man wearing hooded cloak on dexter side of Christ; younger, clean-shaven man wearing hooded tunic on His sinister side.

Inventory of riches: Sumptuous clothes, treasure chest, other (now unidentifiable) objects.

Iconographic context: Devil writing down the conversation between a man and a woman, Man of the Seven Deadly Sins (Dödsyndamannen), St. Michael weighing souls, Labours of Adam and Eve, story of Lazarus and Dives.

Banning (ed.), A Catalogue of Wall-Paintings, II, 88, with further literature; Haastrup (ed.), Danske kalkmalerier: Sengotik, 247; Kaspersen, "Wall-Paintings and Devotion", 207.

10. Fanefjord (Island of Møn, Denmark), parish church, c. 1500-1520 Location: Nave, s. aisle vault.

Christ: Man of Sorrows.

Praying figures: Traditional positions reversed; young, clean-shaven man wearing short, fur-lined tunic and pointed shoes on dexter side of Christ; older, bearded man wearing short, simple tunic and worn shoes (scroll deus pro[p]ici[us] esto mi[hi] pe[ccatori]) on His sinister side; both with rosaries.

Inventory of riches: On right, behind rich man; sumptuous garments on rack, bridled horse, treasure chest, beer barrels.

Iconographic context: Locally venerated saints, Passion cycle, resurrection of Lazarus, Parable of Lazarus and Dives.

Hammer, Sakrale Wandmalerei in Dänemark, 55-56, 64, 121-122, 160; Haastrup (ed.), Danske kalkmalerier: Sengotik, 247-248, with further literature; Jaritz, "Das schlechte Gebet”, 90.

\section{Färentuna (Uppland, Sweden), St. Lars, c. 1470-1480}

The image is combined with a Mass of St. Gregory, substituting the Crucified with the Man of Sorrows; both praying men appear here on the dexter side of Christ. It is located on the east wall of the and appears 
in conjunction with the Fall and Temptation and the Labours of Adam and Eve. No reproduction was available to me at the time of writing.

Cornell, Wallin, Uppsvenska målarskolor, 86; Nilsén, Program och function, 82.

\title{
12. Håbo-Tibble (Uppland, Sweden), parish church, c. 1490, Albertus Pictor(?)
}

Location: Porch, e. wall.

Christ: Man of Sorrows on altar.

Praying figures: Two men in short tunics on dexter side of Christ, one with (now largely illegible) scroll miserere mei deus.

Inventory of riches: House with wine cellar and chamber with treasure chest and sumptuous garments on rack.

Iconographic context: Fall and Temptation, Labours of Adam and Eve, Isaac blessing Jacob, Rebecca and Esau, sinful Sunday hunt.

Armin Tuulse, Kyrkor i Håbo Härad södra delen, Sveriges Kyrkor, VII, 2 (Stockholm: Generalstabens Litografiska Anstalts Förlag, 1962), 340-341; Wildhaber, "Das gute und das schlechte Gebet", 70; Nilsén, Program och function, 91; Melin, Fåfängans förgänglighet, 131.

13. Härkeberga (Uppland, Sweden), parish church, c. 1480-1490, Albertus Pictor

This now fragmentary mural is located on the east wall of the porch, and appears in connection with the Mass of St. Gregory, a Wheel of Fortune, the Fall and Expulsion, the Labours of Adam and Eve, the Judensau, the Temptations of the Devil, the Stigmatization of St. Francis, and the Madonna of the Rosary. No reproduction was available to me at the time of writing.

Pegelow, "Från Helga Lekamen", 215; Cornell, Albertus Pictor, 94; Nilsén, Program och function, 96; Melin, Fåfängans förgänglighet, 237.

\author{
14. Härnevi (Uppland, Sweden), parish church, c. 1470-1480, Albertus \\ Pictor (fig. 1) \\ Location: Porch, vault. \\ Christ: Man of Sorrows, with chalice and array of arma Christi.
}


Praying figures: Older, bearded man with long cloak on dexter side of Christ (scroll miserere deus secundum magnam misericordiam tuam); young, clean-shaven man with long hair, wearing short tunic and pointed shoes on His sinister side.

Inventory of riches: Three-storied, gabled building, containing, among other objects, open treasure chest, sumptuous garments suspended from rod, three tripod cauldrons (Kugeltöpfe), and wine or beer barrels. Iconographic context: St. Martin and St. George, Cloth of Veronica, Madonna of the Rosary, Wheel of Fortune, Death felling Tree of Life.

Cornell, Wallin, Uppsvenska målarskolor, 118; Erik Johan Lundberg, Albertus Pictor (Stockholm: Sveriges Allmänna Konstföreningen, 1961), 29, 245; Wildhaber, "Das gute und das schlechte Gebet", 70; Pegelow, "Från Helga Lekamen", 215-216; Cornell, Albertus Pictor, 86; Nilsén, Program och function, 98; Den gotiska konsten, Signums svenska konsthistoria, 4 (Lund: Atlantis, 1996), 318-319, 408; Melin, Fåfängans förgänglighet, 125-126, 237; Jaritz, "Das schlechte Gebet”, 88.

\section{Hattula (Kanta-Häme, Finland), Holy Cross, c. 1510-1520}

Location: Porch, e. wall.

Christ: Man of Sorrows with chalice.

Praying figures: Traditional positions reversed; young, clean-shaven man with long hair, wearing long robe, on dexter side of Christ; older, bearded man on His sinister side (over niche in wall), with second Man of Sorrows to left.

Inventory of riches: Tripod cauldron, beer barrels, open treasure chest. Iconographic context: Job on the dung heap, Man of Sorrows with arma Christi.

Nilsén, Program och function, 197; Helena Edgren, "Kalkkimaalaukset”, Hattulan ja Tyrvännön kirkot, ed. by Marja Terttu Knapas, Suomen Kirkot; Finlands Kyrkor, 20.1 (Helsinki: Museovirasto, 1997), 50, 94; Melin, Fåfängans förgänglighet, 123.

16. Hökhuvud (Uppland, Sweden), parish church, 1534

The image has been fused with that of a Gregorymass.

Location: Porch, vault.

Christ: Man of Sorrows standing in tomb, supported by angel, surrounded by arma Christi.

Praying figures: Pious man to dexter side of Christ obliterated; younger man with long, fur-lined mantle to His sinister side. 
Inventory of riches: Two-storied, tower-like stone house, containing the distracted man's family (wife with mirror, son and daughter), open treasure chest, various containers, including three goblets, and sumptuous fabric.

Iconographic context: Sacrifice of Abel and Cain, Cain killing Abel, Banishment of Cain, Wheel of Fortune.

Pegelow, "Från Helga Lekamen", 216; Mereth Lindgren, Att lära och att pryda: Om efterreformatoriska kyrkmålningar i Sverige circa 1530-1630 (Stockholm: Kungl. Vitterhets historie och antikvitets akademien, 1983), 43, 241, 292; Nilsén, Program och function, 100; Melin, Fåfängans förgänglighet, 123.

\section{Husby-Sjutolft (Uppland, Sweden), parish church, c. 1475, Albertus Pictor (signed)}

Location: Porch, vault.

Christ: Man of Sorrows, standing on altar.

Praying figures: Older, bearded man with pilgrim's attire and man with carpenter's axe on dexter side of Christ (scroll miserere mei deus secundum magnam misericordiam tuam); younger, clean-shaven man with long, curly hair, wearing short, belted tunic and pointed shoes on His sinister side (scroll, inscribed in Old Swedish min här drak naplega y dach).

Inventory of riches: Three-storied building with arcaded openings, containing scenes of servant inspecting treasure chest, beer barrels, couple in bed with rich fabrics suspended above them.

Iconographic context: Youth in Tree of Life, Wheel of Fortune, Cloth of Veronica, scenes of Christ and saints overcoming evil / the Devil.

Cornell, Wallin, Uppsvenska målarskolor, 117; Wildhaber, “Das gute und das schlechte Gebet”, 68, 70; Kretzenbacher, "Ein Innviertler Mahnbild-Fresko", 122; Cornell, Albertus Pictor, 83; Nilsén, Program och function, 89, 417; Haastrup (ed.), Danske kalkmalerier: Sengotik, 59; Melin, Fåfängans förgänglighet, 123-125, 238; Roger Andersson, “Albertus Pictor och svenska språket”, Den mångsidige målaren, 15-16.

18. Keldby (Island of Møn, Denmark), parish church, c. 1500-1525 Location: Nave, n. vault.

Christ: Crucified.

Praying figures: Bearded older man wearing simple short tunic on dexter side of Christ (scroll deus p[ro]pici[us] esto micchi peccato[ri]); long-haired younger man wearing richer short tunic on His sinister side (scroll misere[re] mei deus); both with rosaries. 
Inventory of riches: Sumptuous garments on rod, treasure chest, bridled horse; below cross female cook preparing food over open fire. Iconographic context: Creation of Eve, Fall and Expulsion, Labours of Adam and Eve.

Rudolf Broby-Johansen, Den danske billedbibel: de midelalderlige kalkmalerier i den danske kirker (Copenhagen: Gyldendalske Boghandel, 1947), 174-175; Wildhaber, "Das gute und das schlechte Gebet", 70; Hammer, Sakrale Wandmalerei in Dänemark, 173; Kretzenbacher, "Ein Innviertler MahnbildFresko", 122; Nils-Arvid Bringéus, Volkstümliche Bilderkunde (Munich: Callwey, 1982), 25-26; Haastrup (ed.), Danske kalkmalerier: Sengotik, 31, 251, with further literature; Wisselaar, "Evagationes spiritus", 166; Kaspersen, "Wall-Paintings and Devotion”, 207; Jaritz, "Das schlechte Gebet”, 88.

\section{Lucéram (Alpes Maritimes, France), Chapelle Notre-Dame-de- Boncœur, c. 1480, Giovanni Baleison}

Portions of the right half of the mural with the rich man and his house of treasures have been obliterated.

Location: S. wall.

Christ: Crucified (at base of cross scroll Si cor non orat in vanu[m] lingua labo[r]at).

Praying figures: Older, bearded man wearing pilgrim's attire on Christ's dexter side; (only partially intact figure of) man wearing pleated and furlined tunic or houppelande on His sinister side; both men and Crucified depicted in mountainous landscape setting, with chapel above pious man and house of riches behind distracted man.

Inventory of riches: Gabled house (largely obliterated).

Iconographic context: Paired with Sunday Christ on opposite n. wall; chapel also contains scenes from the lives of Virgin Mary and St. Sebastian, figures of various locally venerated saints, and Gregorian Man of Sorrows.

Georg Troescher, Burgundische Malerei: Maler und Malwerke um 1400 in Burgund, dem Berry mit der Auvergne und in Savoyen mit ihren Quellen und Ausstrahlungen (Berlin: Deutscher Kunstverlag, 1966), 328; Wildhaber, "Das gute und das schlechte Gebet", 70; Philippe de Beauchamp, L'art religieux dans les Alpes-Maritimes: architecture religieuse, peintures murals et retables (Aix-en-Provence: Édisud, 1993), 65-66; Kretzenbacher, "Ein Innviertler Mahnbild-Fresko", 122; Rigaux, Le Christ du dimanche, 135-138, 346-347; Germaine-Pierre Leclerc, Chapelles peintes du pays niçois (Aix-en-Provence: Edisud, 2006), 54; Paul Roque, Les Peintres primitifs niçois: Guide illustré (Nice: Serre, 2006), 208. 
20. Madrid, Prado, panel painting, c. 1510-1520, Flemish workshop The panel depicts, rather unusually, an Eyckian church interior in which a priest celebrates the eucharist. The two praying figures are arranged on either side of the altar crucifix - host axis, and their traditional positions are reversed.

Christ: Crucified on altar cross.

Praying figures: Fat, clean-shaven man wearing sumptuous fur-lined garments on dexter side of Christ; bearded, lean man wearing short tunic with belted purse on His sinister side; both men of advanced age. Inventory of riches: Four-storied brick house with crenellations, its interior spaces revealing, from top to bottom, servant hoisting sack of grains into attic granary, woman with mirror, cooks preparing meal, stabled horses, wine barrels and bales.

De Tervarent, “En marge du catalogue”; Inventario general de pinturas, I: La Colección Real (Madrid: Museo del Prado, 1990), 138; Wisselaar, “Evagationes spiritus”, 166.

21. Munich, Staatliche Graphische Sammlung; coloured woodcut, c. 1430-1460, (?) Bavarian master (fig. 8)

Christ: Crucified.

Praying figures: Bearded man wearing (pilgrim's) cloak and holding rosary on dexter side of Christ, with angel above; bearded and coiffed man wearing short houppelande and pointed shoes on His sinister side, with devil above.

Inventory of riches: Six scenes or panels, five in a domestic setting woman with mirror in dining room(?), bedroom, table laden with goblet, beakers and plate, open treasure chest with money belts, sumptuous fabrics hanging from rods in three scenes; servant with horse, wine barrels and bales; house with orchard, surrounded by wattle fence.

Iconographic context: Single-leaf woodcut, pasted together with two other woodcuts into a collection of pastoral-didactic treatises, Cod. lat. 12714, which originated in the Augustinian Monastery of Ranshofen near Braunau am Inn.

Philipp Maria Halm, “Ikonographische Studien zum Armen-Seelen-Kultus”, Münchner Jahrbuch der bildenden Kunst, 12 (1921-1922), 17-18; Wilhelm Ludwig Schreiber, Handbuch der Holz-und Metallschnitte des XV. Jahrhunderts, 2: Holzschnitte mit Darstellungen der Heiligen Dreifaltigkeit, Gottvaters, Jesu Christi und der Jungfrau und Gottesmutter Maria, Nr. 736-1173 (Stuttgart: Anton Hiersemann, 1926; repr. Nendeln: Klaus, 1969), 89; De Tervarent, “En marge du catalogue”, 59; 
Wildhaber, "Das gute und das schlechte Gebet", 69; Kretzenbacher, "Ein Innviertler Mahnbild-Fresko", 121; Bringéus, Volkstümliche Bilderkunde, 25-26; Hammer, Sakrale Wandmalerei in Dänemark, 121; Richard S. Field (ed.), The Illustrated Bartsch, 163 (Supplement): German Single-Leaf Woodcuts before 1500 (New York: Abaris, 1990), 276; Kretzenbacher, "Drei altösterreichische Mahnbild-Zeugnisse", 131; Wisselaar, "Evagationes spiritus", 165-166; Jaritz, "Ira Dei, Material Culture”, 53; Lentes, "Inneres Auge, äußerer Blick”, 185-186; Melin, Fåfängans förgänglighet, 123; Jaritz, "Das schlechte Gebet”, 86; Abel, Johannes Nider, 405-406.

\section{Nowe Miasto Lubawskie (Ger.: Neumark) (Warmia-Masuria, Poland), St. Thomas, c. 1440-1450 \\ Location: Nave, s. aisle. \\ Christ: Crucified.}

Praying figures: Man wearing pilgrim's attire on dexter side of Christ; man with fur hat and rich garments on His sinister side. Inventory of riches: Castle on high, rocky promontory. Iconographic context: Independent image; Evangelist symbols from the second half of the fifteenth century in vault of same bay.

Alicja Karłowska-Kamzowa (ed.), Materiały do katalogu gotyckich malowideł ściennych w Polsce (Poznań: Wydawnictwo Naukowe UAM, 1981), 136; Jerzy Domasłowski, Alicja Karłowska-Kamzowa, Marian Kornecki, Helena Małkiewiczówna, Gotyckie malarstwo ścienne w Polsce (Poznań: Wydawnictwo Naukowe UAM, 1984), 141; Jerzy Domasłowski, Alicja Karłowska-Kamzowa, Adam S. Labuda, Malarstwo gotyckie na Pomorzu Wschodnim (Warsaw \& Poznań: Państwowe Wydawnictwo Naukowe, 1990), 58; Nilsén, Program och function, 418-419.

23. Ortisei (Ger.: St. Ulrich im Gröden) (Alto Adige, Italy), St. James, c. 1452-1460, Leonhard von Brixen and workshop (fig. 11)

The image has been fused with that of the Sunday Christ, who is surrounded both by the arma Christi and by a panoramic tableau of various labours and activities prohibited on Sundays and Feast Days. The pious man has disappeared beneath an eighteenth-century mural of one of the Stations of the Cross, though some of his thought- and prayer-lines still remain visible.

Location: Nave, exterior, s. wall.

Christ: Man of Sorrows, surrounded by utensils and scenes representing Sunday labour.

Praying figures: Pious man on dexter side of Christ now completely obliterated; bearded, young man wearing fur-trimmed clothes (hat, short tunic) and belted purse on His sinister side (inscription below Gedankt des reichen / blickend auf sein beib und / auf sein gut das mit-nichten gwunen ist). 
Inventory of riches: Single-storied, crenellated house, containing woman in bed, treasure chest, surrounded by scenes of woman with mirror, man with crossbow, groom with horse, all including figures of small demons. Iconographic context: Independent image.

Rigaux, Le Christ du dimanche, 135-138, 330-331, with further literature.

\section{4. Österunda (Uppland, Sweden), parish church, c. 1490, Albertus Pictor (?)}

Location: Porch, vault

Christ: Man of Sorrows, standing on altar.

Praying figures: Older, bearded man with short, belted tunic on Christ's dexter side; younger, clean-shaven man with long hair, wearing short, belted tunic and pointed shoes, on His sinister side.

Inventory of riches: Multi-storied house (largely obliterated), in which servant inspecting open treasure chest can still be discerned.

Iconographic context: Wheel of Fortune, Temptations of the Devil, various saints.

Wildhaber, "Das gute und das schlechte Gebet”, 70; Kretzenbacher, "Ein Innviertler Mahnbild-Fresko", 122; Cornell, Albertus Pictor, 98; Nilsén, Program och function, 183; Melin, Fåfängans förgänglighet, 241.

\section{Polling (Oberösterreich, Austria), parish church, c. 1480-1500}

Location: Nave, exterior, w. wall.

Christ: Crucified.

Praying figures: Young man in short tunic on dexter side of Christ; young man wearing sumptuous, fur-lined mantle on His sinister side. Inventory of riches: Crenellated stone house with arcaded window, in which rich tableware, horse, wine barrels, tableware, wife and maid or child are visible.

Iconographic context: Independent image.

Kretzenbacher, "Ein Innviertler Mahnbild-Fresko", 122; Kretzenbacher, "Drei altösterreichische Mahnbild-Zeugnisse”, 128-131; Jaritz, "Das schlechte Gebet”, 88. 
26. Ptuj (Ger.: Pettau) (Štajerska, Slovenia), St. George, c. 1430-1440 (fig. 6)

Location: Nave, n. wall.

Christ: Crucified, flanked by Virgin Mary on dexter side and St. John Ev. and St. Peter on His sinister side.

Praying figures: Both praying men on dexter side of Christ; pious young man with belted tunic below cross; behind him, older bearded man wearing long-sleeved mantle with his family (wife, two sons, two daughters). Inventory of riches: House with gated courtyard, above rich man's family, in which wine barrels, open treasure chest and stabled horses are on display.

Iconographic context: Independent image.

Kretzenbacher, "Drei altösterreichische Mahnbild-Zeugnisse", 134-138, with further literature; Jaritz, "Das schlechte Gebet", 90.

27. Regensburg (Bayern, Germany), Historisches Museum, Poor Souls' Triptych (Armeseelenaltar of Elisabeth and Sigmund Graner), 1488

Location: The altarpiece was initially commissioned for the Graner's family chapel in the Collegiate Church of Our Lady (Unsere Liebe Frau zur Alten Kapelle) in Regensburg. The allegory of the Good and Bad Prayer is, like the other scenes on the interior of the triptych, sculpted, and initially featured sets of prayer-lines fashioned from wire; the image is located above one of the Seven Works of Mercy (Feeding the Hungry) in the upper register of the left wing.

Christ: Crucified.

Praying figures: Short-haired cleric on dexter side of Christ; long-haired layman wearing short tunic and pointed shoes on His sinister side.

Inventory of riches: Three-storied house with six interior spaces, revealing: treasure chest and hanging cupboard, woman with mirror (top); couple in bed, Doppelpokal on large locked trunk or chest (middle); wine barrels, groom with horse (bottom).

Iconographic context: Last Judgment with donor family, fons vitae, Madonna of Mercy, elevation of the eucharist (Poor Souls' Mass), Seven Works of Mercy, Purgatory (interior, all scenes carved and polychromed); St. Simon and St. Bartholomew, Savator mundi and Virgin Mary (exterior, painted). 
Halm, "Ikonographische Studien", 17-18; De Tervarent, "En marge du catalogue”, 59; Craig Harbison, The Last Judgment in Sixteenth-Century Northern Europe: A Study of the Relation between Art and the Reformation (New York: Garland, 1976), 106-109; Gerhard Bott (ed.), Martin Luther und die Reformation in Deutschland (Frankfurt a. M.: Insel, 1983), 334-335; Hartmut Boockmann, Die Stadt im späten Mittelalter (Munich: Beck, 1986), 214-215; Dasein und Vision: Bürger und Bauern um 1500 (Berlin: Henschelverlag, 1989), no. A106; Hartmut Boockmann, "Belehrung durch Bilder? Ein unbekannter Typus spätmittelalterlicher Tafelbilder”, Zeitschrift für Kunstgeschichte, 57 (1994), 18; Peter Jezler (ed.), Himmel, Hölle, Fegefeuer: Das Jenseits im Mittelalter (Zürich: Verlag Neue Zürcher Zeitung, 1994), 190-191; Martin Angerer (ed.), Regensburg im Mittelalter: Katalog der Abteilung Mittelalter im Museum der Stadt Regensburg (Regensburg: Universitätsverlag, 1995), 163-164, with further literature; Wisselaar, "Evagationes spiritus", 166; Marti, Malen, Schreiben und Beten, 214; Jaritz, "Das schlechte Gebet”, 91.

\section{Röddinge (Skåne, Sweden), parish church, c. 1500}

Location: Nave, w. vault.

Christ: Man of Sorrows.

Praying figures: Man on dexter side of Christ fragmentary; man wearing pointed shoes on His sinister side.

Inventory of riches: Treasure chest and other items of furniture.

Iconographic context: Last Judgment, St. Michael weighing the souls, Man of Seven Deadly Sins (Dödsyndamannen).

Wildhaber, "Das gute und das schlechte Gebet", 70; Banning (ed.), A Catalogue of Wall-Paintings, 3 (1976), 58-59, with further bibliography; Kretzenbacher, "Ein Innviertler Mahnbild-Fresko", 122; Kaspersen, "Wall-Paintings and Devotion", 207.

\section{Rome, Biblioteca Casanatense, Miscellany, Ms. 1404 (Codex Casanatensis), c. 1425-1440 (fig. 9)}

Location: Fol. 2r.

Christ: Crucified, in wayside shrine, flanked by Virgin Mary and John Ev. Praying figures: Clean-shaven man wearing short tunic with purse on dexter side of Christ; bearded man wearing short, fur-lined tunic and bi-coloured trousers on His sinister side.

Inventory of riches: Two-storied house with porch within crenellated enclosure, in which are shown large ewer, clothes on rack, open, compartmentalized treasure chest.

Iconographic context: Wheel of Fortune, woman with mirror (superbia), various allegories on the fickleness of fate. 
30. Särslöv (Skåne, Sweden), parish church, c. 1500

Documented, but no longer surviving.

Location: Nave, vault.

Iconographic context: Prophets, bishop saints, Creation scenes.

Banning (ed.), A Catalogue of Wall-Paintings, III, 126, with further literature.

31. Scena (Ger.: Schenna) (Alto Adige, Italy), St. George, c. 1390-1400 (fig. 5)

Fragment; only central and right portion of image survive.

Location: Nave (rotunda), n. wall.

Christ: Crucified.

Praying figures: Fragment of bearded man (scroll domine...) on dexter side of Christ; bearded man, with carpenter's axe (scroll domine exaudi [h]oracionem meam et clamor me[us] ad te/veniat traedicitij in rengno [sic] patris [Psalm 101:2]), veiled woman (scroll venite benedicti in regno [?] patris [Matthew 25:34]), both on His sinister side; above them above them three angels with scroll introitus domine laudam[us] te benedicim[us] te adoram[us] te glorificam[us] te.

Inventory of riches: Lost.

Iconographic context: Narrative cycles of lives of St. George and St. Nicholas.

Ingrid Flor, "Die gotischen Fresken der Fronbogenwand von St. Proklus zu Naturns in Südtirol: Zur Bildsprache der Mystik im späten Mittelalter”, Geschichtsforschung in Graz: Festschrift zum 125-JahrJubiläum des Instituts für Geschichte der Karl-Franzens-Universität Graz (Graz: Institut für Geschichte, 1990), 58; Kretzenbacher, "Drei altösterreichische Mahnbild-Zeugnisse”, 138-139.

\section{Schwerin (Mecklenburg-Vorpommern, Germany), Staatliches} Museum, panel painting, c. 1535, circle or follower of Hans Schäufelein Christ: Crucified.

Praying figures: Older, bearded man dressed in black mantle assisted by angels on dexter side of Christ; younger man, perhaps a Landsknecht, with unkempt hair and extravagant, brightly coloured clothing (puffed and slashed doublet and hose), looking away from Christ and flanked by two devils, on His sinister side; both men with rosaries. 
Inventory of riches: Panoramic landscape with steep mountains in backand middleground, in which various 'male' adventures and pastimes are depicted: jousting, hunting, gambling (with two men fighting), banqueting and drinking (with one man vomiting), lovemaking, music-making, dancing; house of riches in right middleground, with horse stable and open treasure chest; the whole composition loosely based on a broadside entitled Die eytel vergengklich Freudt on(d) wollust diser welt (Nuremberg, 1534), which pairs a woodcut by Erhard Schoen with a poem by Hans Sachs.

Iconographic context: Independent panel painting.

Friedrich Schlie, Beschreibendes Verzeichnis der Werke älterer Meister in der Grossherzoglichen Gemäldegalerie zu Schwerin (Schwerin: Bärensprung, 1882), no. 933; Deutsche Kunst der DürerZeit (Dresden: Nationaler Museumsrat der DDR, 1971), 260-261; Kunst der Reformationszeit (Berlin: Henschelverlag, 1983), 362; Kristina Hegner, Kunst der Renaissance (Schwerin: Staatliches Museum, 1990), 17-18; Christoph Metzger, Hans Schäufelin als Maler (Berlin: Deutscher Verlag für Kunstwissenschaft, 2002), 557.

\section{Søborg (Sjælland, Denmark), parish church, 1400-1420}

The mural is in a delicate condition, with the two flanking figures being barely visible; there are traces of prayer lines and an inventory of riches.

Location: Nave, pier.

Christ: Crucified.

Praying figures: Bearded older man with long mantle on dexter side of Christ; clean-shaven younger man with short tunic on His sinister side. Inventory of riches: Lost.

Iconographic context: Various saints, Trinity, Madonna of the Apocalypse.

Melin, Fåfängans förgänglighet, 238.

\section{Sollentuna (Uppland, Sweden), parish church, 1483, Albertus Pictor Location: Porch, vault.}

Christ: Crucified.

Praying figures: Bearded pilgrim with (now illegible) scroll on dexter side of Christ; young man wearing short tunic and pointed shoes on His sinister side.

Inventory of riches: Three-storied house with (now illegible) scenes. Iconographic context: Mass of St. Gregory, Wheel of Fortune. 
Armin Tuulse, Kyrkor i Sollentuna Härad södra delen, Sveriges Kyrkor, VI.4 (Stockholm: Generalstabens Litografiska Anstalts Förlag, 1958), 620; Wildhaber, “Das gute und das schlechte Gebet”, 70; Kretzenbacher, Ein Innviertler Mahnbild-Fresko, 122; Pegelow, "Från Helga Lekamen”, 216; Nilsén, Program och function, 134; Melin, Fåfängans förgänglighet, 126-127, 238.

\section{Strasbourg (Alsace, France), Musée de l'CEuvre de Notre Dame; panel painting, 1474 (fig. 12)}

This image fuses the allegory of the Good and Bad Prayer with that of Lazarus and Dives. While the distracted man is identified by his house of riches, the poor and pious man is paired with the house of Dives, in and around which the events of the parable are narrated. Uniquely, in this panel, the prayer or thought lines do not issue from the mouths of the praying men, but are attached to their hands and feet, recalling the stigmata of St. Francis of Assisi.

Christ: Man of Sorrows (scroll O mensch sich an mich / wasz groser not laid ich willig / und arm bist ufferden / solt du ain burger in minem reich warden). Praying figures: Clean-shaven man wearing long, hooded mantle on dexter side of Christ; younger, clean-shaven man with long, flowing hair wearing fur-lined houppelande on His sinister side; below them Death as cadaver, framed by banderole (O mentsch syech an mich das $d u$ bist des was ich) and large inscribed field (O mentsch folg miner ler / diech von dinen sünden Kör / du must sterben das waist du woll / und waist doch nit wenn das geschehen soll. $\mathrm{M}^{\circ} \mathrm{CCCC}^{\circ} \mathrm{LXX}$ IIII $^{\circ}$ jar).

Inventory of riches: Four-storied house, its arcaded openings revealing, from top to bottom, rich tableware (ewers, beakers, goblets etc.), treasure chest and bales of wares, woman with mirror by large, canopied bed, cellar with wine barrels.

Iconographic context: On right, behind pious man, Parable of Lazarus and Dives, narrated in five detailed scenes - banquet and death of Dives (in tall house that forms pendant to house of riches), death of Lazarus and the respectives fates of the souls of Lazarus (received in Abraham's bosom, with scroll Vater aberham lass lasrus mit dem minsten vinger ... geben ain tropfen wassers uff die zungen und ...) and Dives (swallowed by Maw of Hell, with scroll Dar umb das du lazarus hast verschmacht ufferden / dar umb so mag dir der tropff wasers nit warden). 


\section{Tensta (Uppland, Sweden), parish church, c. 1500}

Fragmentary.

The image has been fused with that of a Gregorymass.

Location: Porch, e. wall.

Christ: Man of Sorrows, standing in tomb, framed by arma Christi and flanked by pair of angels holding His cloth of honour.

Praying figures: Clean-shaven, young man with simple tunic on Christ's dexter side; richly dressed man and his family (all now largely obliterated) on His sinister side.

Inventory of riches: Multi-storied house (almost entirely lost).

Iconographic context: Death and the Youth, various allegorical scenes.

Nilsén, Program och function, 146; Melin, Fåfängans förgänglighet, 123.

\section{Tingsted (Island of Møn, Denmark), parish church, c. 1500}

Location: Nave, e. vault.

Christ: Man of Sorrows.

Praying figures: Older, bearded man wearing pilgrim's attributes and worn clothing and shoes on dexter side of Christ (scroll deus gratia esto in peccatore); younger, clean-shaven man wearing fur-lined robe, belted purse and dagger, and pointed shoes on His sinister side (scroll miserere mei deus); both with rosaries.

Inventory of riches: Surmounted by gabled roof; sumptuous clothes on rack, treasure chest, wine barrel, bridled horse.

Iconographic context: Fall and Expulsion, Wheel of Fortune.

Hammer, Sakrale Wandmalerei in Dänemark, 203; Haastrup (ed.), Danske kalkmalerier: Sengotik, 259, with further literature.

38. Venanson (Alpes Maritimes, France), Chapel of St Sebastian, 1481, Giovanni Baleison (signed)

Location: S. wall.

Christ: Crucified (at base of cross scroll with largely obliterated inscription).

Praying figures: Older, bearded man wearing pilgrim's attire on Christ's dexter side; younger, clean-shaven man wearing short, fur-lined tunic 
on His sinister side; both men and Crucified depicted in mountainous landscape setting with fields and orchards; above pious man forest, distant town and chapel, behind distracted man house of riches.

Inventory of riches: Two-storied, crenellated stone house with arcaded window, in which treasure chest is displayed.

Iconographic context: Paired with Sunday Christ on opposite n. wall; chapel also contains representations of Virtues and Vices (largely lost), cycle of life of St. Sebastian and figures of locally venerated saints.

Victor-Henry Debidour, Trésors cachés du Pays Niçois (Paris: Hachette, 1961), 126; Troescher, Burgundische Malerei, 330; Wildhaber, "Das gute und das schlechte Gebet," 70; Rigaux, Le Christ du dimanche, 135-138, 348-351; Leclerc, Chapelles peintes, 54, 129, 161; Roque, Les Peintres primitifs niçois, 246.

\section{Vienna, Graphische Sammlung Albertina, engraving, 1565, Matteo Cartaro}

Christ: Crucified, with cross above canopied altar.

Praying figures: Beardless young pilgrim, nudis pedibus, in shabby tunic, on dexter side of Christ; bearded and coiffed older man wearing slashed doublet, mantle, and leather boots on His sinister side.

Inventory of riches: Expansive landscape occupying left and right middle- and background; on left, above pious man, house with woman and child, servant and dog, and, at top merchant ship; on right, above distracted man, scene of stag hunt.

Iconographic context: Independent print.

Suzanne Boorsch, John Spike (eds.), The Illustrated Bartsch, 31: Italian Artists of the Sixteenth Century, (New York: Abaris, 1986), 422; Ulrich Heinen, Rubens zwischen Predigt und Kunst: Der Hochaltar der Walburgenkirche in Antwerpen (Weimar: VDG, 1996), 222 n. 285; David Ganz, "Die Crux des wahren Bildes: Die Maler des kreuztragenden Christus in einem Titelkupfer Theodoor Galles", Golgatha in den Konfessionen und Medien der Frühen Neuzeit, ed. by Johann Anselm Steiger, Ulrich Heinen, Arbeiten zur Kirchengeschichte, 113 (Berlin \& New York: de Gruyter, 2010), 310.

40. Wismar (Mecklenburg-Vorpommern, Germany), Heilig-GeistKirche, c. 1380-1400 (fig. 3)

Fragment; only right portion of image without Christ and praying men survives. Location: Nave, n. wall, above door formerly leading to cemetery. The mural depicts the object(s) of the (lost) distracted figure's thoughts: three-storied house with stepped gable and two interior levels, contain- 
ing, from top to bottom, woman with mirror, treasure chest, large bed with stuffed pillows, and rack of sumptuous garments (bedroom), cook with roasting spit below large fireplace (kitchen), horses drinking from water barrels (stable).

Iconographic context: Three Living and Three Dead (fragmentary), on opposite wall.

Nickel, Mittelalterliche Wandmalerei in der DDR, 295; Nilsén, Program och function, 418-419; Michel Bunners, Das Heiligen-Geist-Hospital zu Wismar, Peda-Kunstführer, 125 (Passau: Kunstverlag Peda: 2003), 12-13.

\section{Yttergran (Uppland, Sweden), parish church, 1480, Albertus Pictor} Location: Porch, vault.

Christ: Man of Sorrows standing on altar.

Praying figures: Older, bearded man in pilgrim's attire on dexter side of Christ (scroll [m]iserere mei, deus, [second] um magnam XC); young, clean-shaven man with curly hair, wearing short tunic, belted purse, and pointed shoes on His sinister side.

Inventory of riches: Three-storied building, in which are depicted scenes of man inspecting treasure chest, cook in his kitchen, and servant decanting beer or wine from barrel.

Iconographic context: Wheel of Fortune, Three Living and Three Dead, various Temptations of the Devil.

Cornell, Wallin, Uppsvenska målarskolor, 121; Armin Tuulse, Kyrkor i Håbo Härad mellersta delen, Sveriges Kyrkor, VII.3 (Stockholm: Generalstabens Litografiska Anstalts Förlag, 1963), 477-478; Cornell, Albertus Pictor, 88; Nilsén, Program och function, 174; Melin, Fåfängans förgänglighet, 127-128, 240. 
Achim Timmermann: Good and Bad Prayers

Keywords: Allegory, MURAl paining, Albertus Pictor, PRAYer, MATerial CULTURE, CRUCIFIXION, CHURCH REFORM

\section{SUMmary:}

The article represents the first comprehensive examination of the late medieval image of the Good and Bad Prayer, a complex and rare visual allegory of the treasures of Heaven and the treasures of earth (Matthew 6:19-21, 24) created sometime during the first half of the fourteenth century and still in use during the second half of the sixteenth. Focusing on the early history of the image, from its likely inception in a monastic milieu to its wider dissemination by itinerant muralists in Denmark and Sweden during the 1470s - 1490s - the workshop of Albertus Pictor being a chief case in point - the analysis is embedded in a wider discussion of late medieval pictorial didacticism, of attitudes toward materialism and conspicuous consumption, and of the later fourteenth- and fifteenth-century culture of lay prayer. A preliminary catalogue of the forty or so known examples of the Good and Bad Prayer concludes this investigation.

CV:

Achim Timmermann is Associate Professor at the Department of the History of Art at the University of Michigan, Ann Arbor, where he teaches medieval and northern Renaissance art and architecture. His current research interests include the pictorial and architectural stage-management of the body of Christ, the role of public monuments in medieval civic and rural life, and late medieval allegory. He is author of Real Presence: Sacrament Houses and the Body of Christ, c. 1270-1600 (2009), of the forthcoming monograph Representation and Redemption: Sacred Landscape and the Late Medieval Public Monument, and of over thirty articles on various aspects of medieval and Renaissance visual and architectural culture. 